
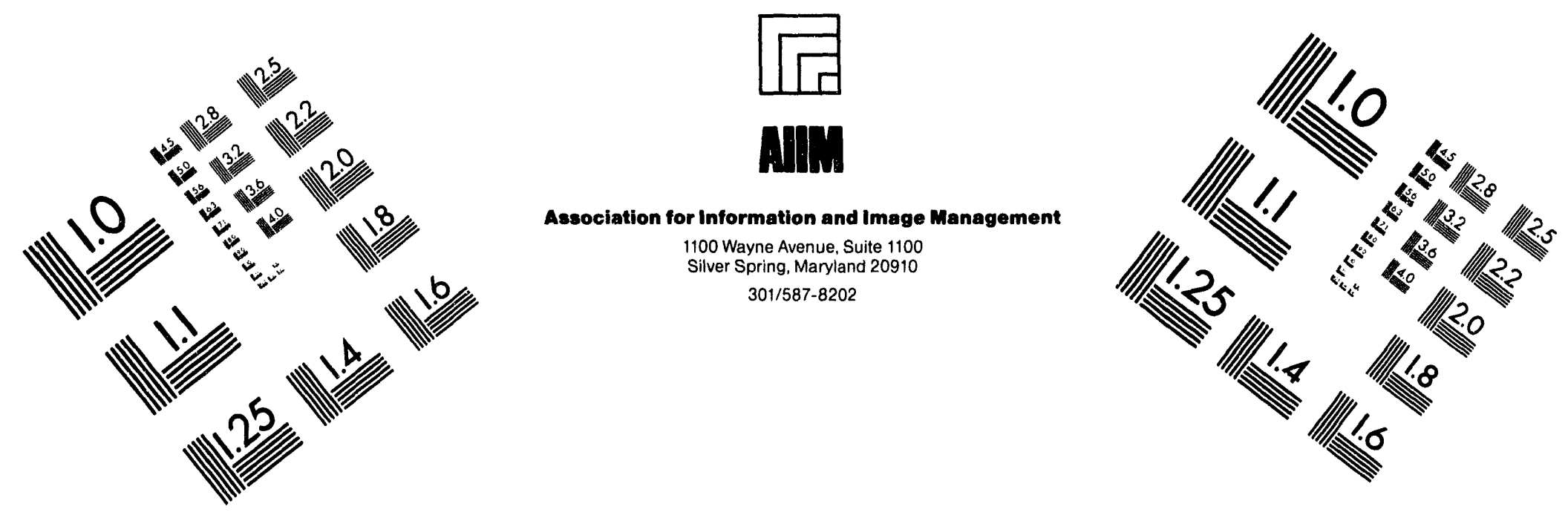

Centimeter

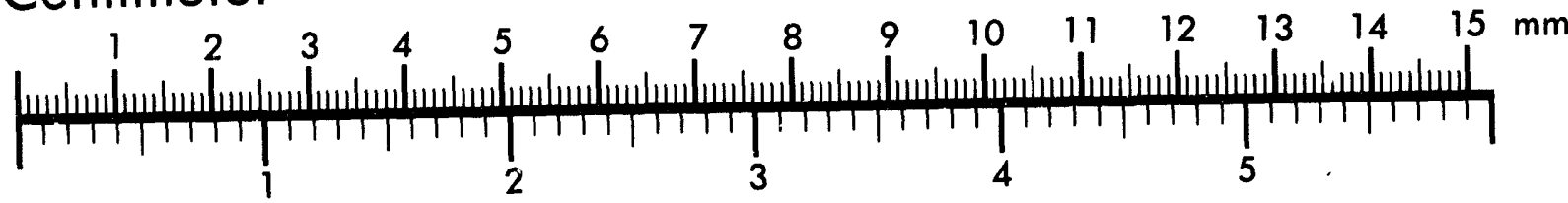
Inches
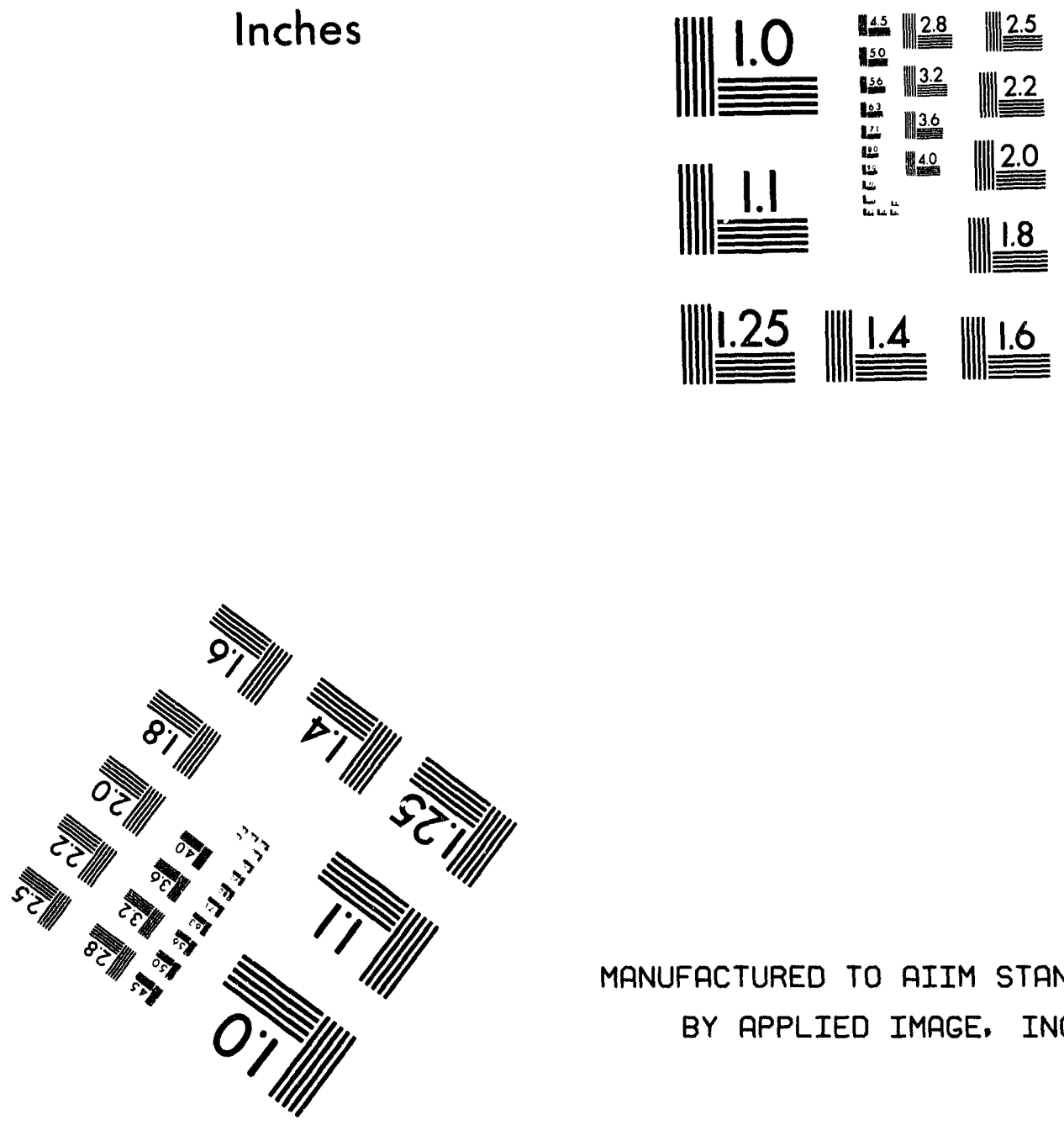

MANUFACTURED TO AIIM STANDARDS BY APPLIED IMAGE, INC.

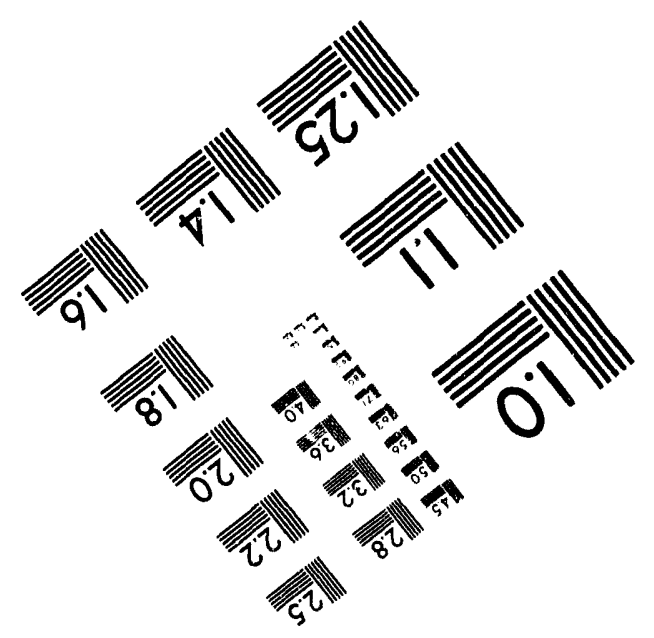



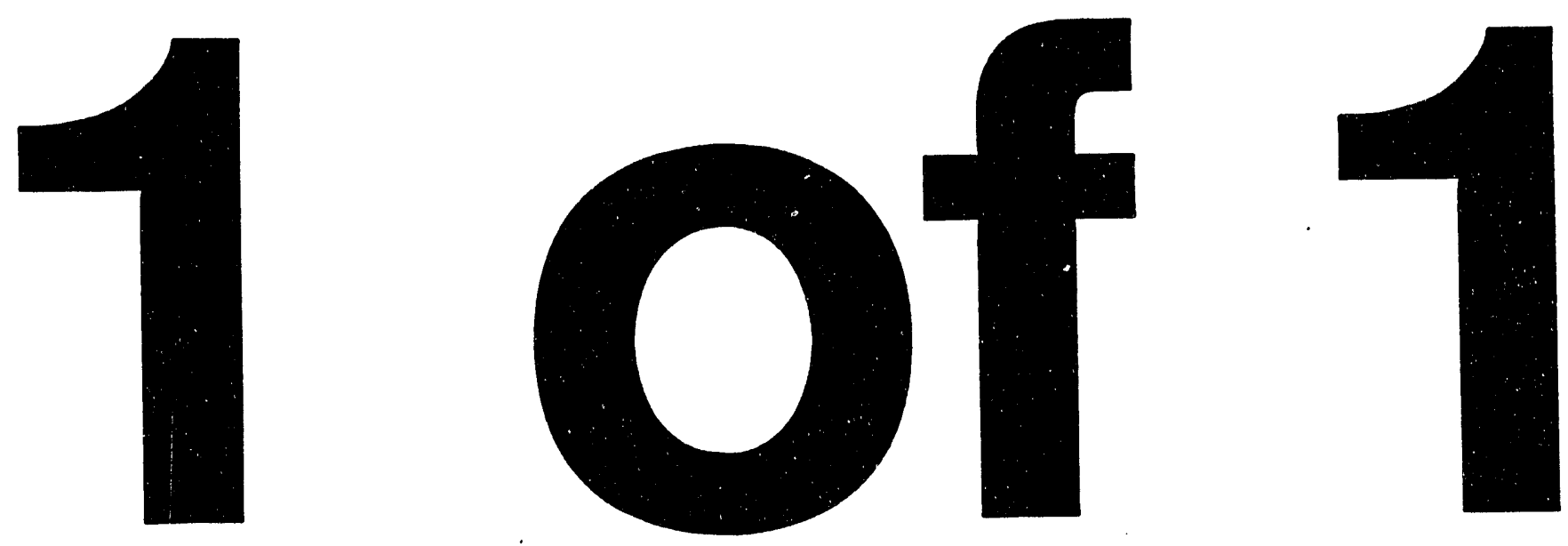
Engineering Physics and Mathematics Division

\title{
VULNERABILITY ASSESSMENT OF A SPACE BASED WEAPON PLATFORM ELECTRONICS SYSTEM EXPOSED TO A THERMONUCLEAR WEAPON DETONATION
}

\author{
C. L. Perez
}

J. O. Johnson

University of North Carolina

Chapel Hill, North Carolina, 27514

DATE PUBLISHED - May 1994

This work is sponsored by the Defense Nuclear Agency under MIPR 1894, and DOE Interagency Agreement No. 1205-E097-A1

Prepared by

Oak Ridge National Laboratory

Oak Ridge, Tennessee 37831

managed by

MARTIN MARIETTA ENERGY SYSTEMS, INC.

for the

U. S. DEPARTMENT OF ENERGY

under Contract No. DE-AC05-84OR21400 
LIST OF FIGURES $\ldots \ldots \ldots \ldots \ldots \ldots \ldots \ldots \ldots \ldots \ldots \ldots \ldots \ldots \ldots, v$

LIST OF TABLES $\ldots \ldots \ldots \ldots \ldots \ldots \ldots \ldots \ldots \ldots \ldots \ldots \ldots \ldots \ldots \ldots$

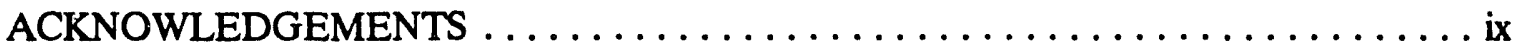

ABSTRACT $\ldots \ldots \ldots \ldots \ldots \ldots \ldots \ldots \ldots \ldots \ldots \ldots \ldots \ldots \ldots \ldots \ldots \ldots \ldots$

$1.0 \quad$ INTRODUCTION $\ldots \ldots \ldots \ldots \ldots \ldots \ldots \ldots \ldots \ldots \ldots \ldots \ldots \ldots \ldots$

2.0 CALCULATIONAL MODEL OF THE SPACE BASED

INTERCEPTOR (SBI) WEAPON PLATFORM $\ldots \ldots \ldots \ldots \ldots \ldots \ldots \ldots, 3$

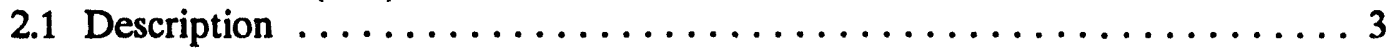

2.2 Details of the SBI Weapon Platform and Interceptors $\ldots \ldots \ldots \ldots \ldots \ldots$

3.0 MASH V1.0 CALCULATIONAL TECHNIQUES $\ldots \ldots \ldots \ldots \ldots \ldots \ldots 13$

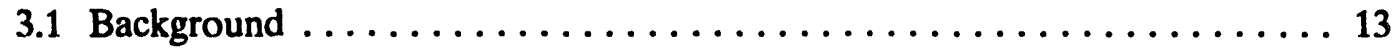

3.2 Definition of Protection and Reduction Factors ............... 15

3.3 Radiation Environment ........................... 15

3.4 The SBI Weapon Platform Geometry Model ................. 19

3.5 The SBI Weapon Platform Calculations ..................... 19

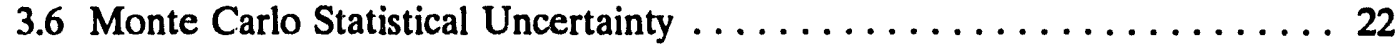

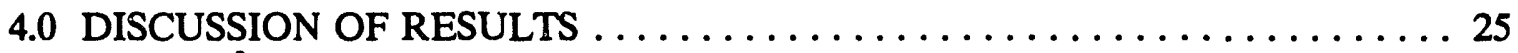

4.1 $\mathrm{C}^{3}$ Bay Critical Components Box Dose (Silicon), Protection Factor,

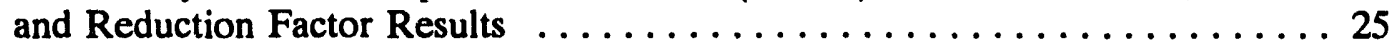

5.0 CONCLUSIONS AND RECOMMENDATIONS $\ldots \ldots \ldots \ldots \ldots \ldots \ldots \ldots$

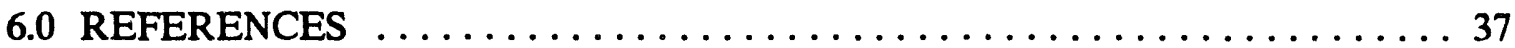




\section{LIST OF FIGURES}

1. Schematic Diagram Illustrating the Calculational Model of the Spaced Based Interceptor Weapon Platform $\ldots \ldots \ldots \ldots \ldots \ldots \ldots \ldots \ldots \ldots$

2. Interior view of the Spaced Based Interceptor Weapon Platform Showing Launch

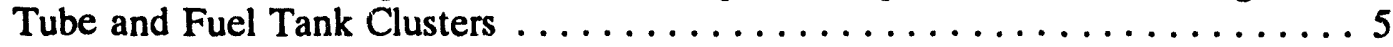

3. Schematic Diagram of the Spaced Based Interceptor Weapon Platform Command, Control, and Communications $\left(C^{3}\right)$ Instrument Bay . . . . . . . . . . 6

4. Schematic Diagram of the Spaced Based Interceptor Weapon Platform Kinetic Kill

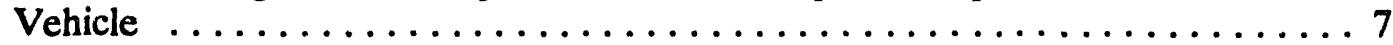

5. Schematic Diagram Illustrating the Kinetic Kill Vehicles Inside the Spaced Based Interceptor Weapon Platform Launch Tubes $\ldots \ldots \ldots \ldots \ldots \ldots \ldots$

6. General Flow Diagram of the MASH v1.0 Code System Applied to a Typical Prompt Radiation Analysis of a Target Vehicle . . . . . . . . . . . . . . . 14

7. Definitions of Neutron, Gamma-Ray, and Total Protection Factors and Reduction Factors Used to Characterize Material Shielding Effectiveness. . . . . . . . . 16

8. Schematic Diagram of the SBI Weapon Platform Orientations Relative to the Thermonuclear Weapon Detonation .................... 26 


\section{LIST OF TABLES}

1. Material Compositions for the SBI Weapon Platform $\ldots \ldots \ldots \ldots \ldots \ldots \ldots$

2. Material Compositions for the SBI Weapon Platform Kinetic Kill

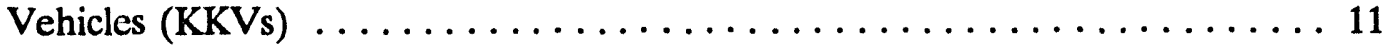

3. DABL69 46 Energy Group Structure, Normalized Thermonuclear Weapon Detonation Neutron Source Spectrum (Number of Neutrons per Energy Bin), and DABL69 Silicon Kerma Response Function $\left(\mathrm{cGy}^{2} \cdot \mathrm{cm}^{2}\right)$ Used in the MASH

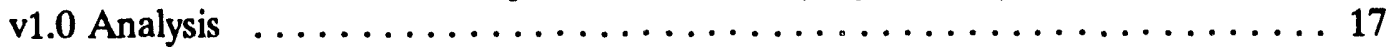

4. DABL69 23 Energy Group Structure, Normalized Thermonuclear Weapon Detonation Gamma-Ray Source Spectrum (Number of Gamma Rays per Energy Bin), and DABL69 Silicon Kerma Response Function $\left(\mathrm{cGy}^{2} \cdot \mathrm{cm}^{2}\right)$ Used in the

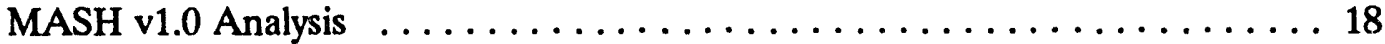

5. SBI Weapon Platform Component Volumes and Masses $\ldots \ldots \ldots \ldots \ldots \ldots$

6. Kinetic Kill Vehicle Component Volumes and Masses (per KKV) . . . . . 21

7. SBI Platform and KKV Material Parameters $\ldots \ldots \ldots \ldots \ldots \ldots \ldots \ldots$

8. Calculated Neutron and Gamma-Ray Free-Field Fluences and Doses for the Silicon Components in the SBI Weapon Platform $\mathrm{C}^{3}$ Bay Critical Components Box Due to a Thermonuclear Weapon Detonation ................ 27

9. Calculated Neutron and Gamma-Ray Doses to the Silicon Components in the SBI Weapon Platform $\mathrm{C}^{3}$ Bay Critical Components Box Due to a Thermonuclear Weapon Detonation: Fully Loaded Platform ............... 28

10. Calculated Neutron and Gamma-Ray Doses to the Silicon Components in the SBI Weapon Platform $\mathrm{C}^{3}$ Bay Critical Components Box Due to a Thermonuclear Weapon Detonation: Center KKVs Launched . . . . . . . . . . . . . . 29

11. Calculated Neutron and Gamma-Ray Doses to the Silicon Components in the SBI Weapon Platform $\mathrm{C}^{3}$ Bay Critical Components Box Due to a Thermonuclear Weapon Detonation: Top and Bottom KKVs Launched ........... 30

12. Calculated Neutron and Gamma-Ray Protection and Reduction Factors for the Silicon Components in the SBI Weapon Platform $\mathrm{C}^{3}$ Bay Critical Components Box Due to a Thermonuclear Weapon Detonation: Fully Loaded Platform ......... 31

13. Calculated Neutron and Gamma-Ray Protection and Reduction Factors for the Silicon Components in the SBI Weapon Platform $\mathrm{C}^{3}$ Bay Critical Components Box Due to a Thermonuclear Weapon Detonation: Center KKVs Launched . . . . 32 
14. Calculated Neutron and Gamma-Ray Doses to the Silicon Components in the SBI Weapon Platform $\mathrm{C}^{3}$ Bay Critical Components Box Due Top and Bottom KKVs

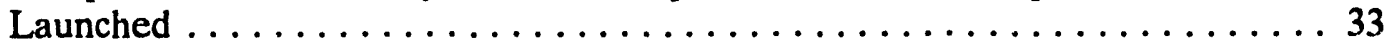




\section{ACKNOWLEDGEMENTS}

The authors would like to thank the Defense Nuclear Agency for continuously supporting the validation and application of the MASH v1.0 code system. The authors would also like to thank Mr. James D. Drischler for his help in the data preparation for this report and Mrs. Sue Shriner for her significant efforts in preparing this manuscript for publication. 


\begin{abstract}
The utilization of reconnaissance/surveillance satellite and weapon platform assets in space will subject the sensitive electronic equipment to a variety of natural and man-made radiation environments. These include Van Allen Belt protons and electrons; galactic and solar flare protons; neutrons, gamma rays, and X-rays from fission and fusion weapons; and directed neutral particle beams and lasers. Electronic equipment, including modern integrated circuits, may undergo permanent or transient changes of the electrical properties of the active components when exposed to these sources of radiation. This report summarizes the results of the Oak Ridge National Laboratory (ORNL) Monte Carlo Adjoint Shielding code system - MASH v1.0 calculations designed to estimate the dose to the critical electronics components of an idealized spaced based weapon platform from neutron and gamma-ray radiation emanating from a thermonuclear weapon detonation. The MASH calculations modeled several source/platform geometry configurations, obtaining results for multiple distances and weapon detonation positions relative to the platform.

For certain source/platform orientatic $₫$, the results indicate vulnerabilities to the $\mathrm{C}^{3}$ bay critical components box to radiation damagu from a nuclear weapon detonation. Neutron protection factors ranged from 0.7 to 3.4 for the three platform configurations analyzed, and gamma-ray protection factors ranged from approximately 1.5 to 9.8. The results further indicate the source has a direct line-of-sight to the critical components box for certain source/platform orientations, regardless of the number of interceptors present. Localized shielding of the $\mathrm{C}^{3}$ bay critical components box (and probably the inner and outer instrument rings) would be necessary to successfully mitigate all radiation line-of-sight pathways into the electronic bays.

The merits of utilizing the MASH code system for estimating dose and shielding factors for spaced based assets has been demonstrated. The geometry configuration studied here is greatly simplified compared to those that will be encountered in an actual design. The MASH code system is capable of estimating the dose in much more complicated geometries and should prove to be an invaluable tool for assessing the radiation effects to electronic equipment from both on-spacecraft and external radiation sources. Combining the MASH code system with other codes that estimate natural radiation effects will provide satellite and weapon platform designers with a full complement of analytic tools.
\end{abstract}




\subsection{INTRODUCTION}

Theater ballistic missiles have been used in several military conflicts beginning with World War II and most recently were used in the Persian Gulf War. The thin layer of short-range ground-based anti-missile defense systems deployed to intercept the incoming theater ballistic missiles could not effectively stop the relatively crude missiles (Iraq modified Scud missiles) used in the Gulf War. Moreover, the Scud missiles were the only weapons that caused substantial casualties and inflicted damage deep inside Saudia Arabia and Israel. This aspect of theater ballistic missile employment and defense is significant considering that Iraq entered the conflict with a million-man army supported by a modern air force with more than 1,000 jet fighters. Due to the moderate effectiveness of the employment of Scud missiles by Iraq, the development, production, and marketing of theater ballistic missiles has emerged as a growth industry.

Rapidly changing world events, the increased number of nations with theater ballistic missile and inter-continental ballistic missile capability, and the proliferation of nuclear weapon technology have increased the number of nuclear threats facing the world today. Many of these nations are run by unstable governments hostile to the United States and her allies. Consequently, monitoring these nation's activities and providing an early warning/intercept system may require a substantial constellation of reconnaissance/surveillance satellites and space based weapon platforms as an adequate deterrent against a surprise nuclear attack.

The utilization of reconnaissance/surveillance satellite and weapon platform assets in space will subject the sensitive electronic equipment to a yariety of natural and man-made radiation environments. These include Van Allen Belt protons and electrons; galactic and solar flare protons; neutrons, gamma rays, and $\mathrm{X}$-rays from fission and fusion weapons; and directed neutral particle beams and lasers. Electronic equipment, including modern integrated circuits, may undergo permanent or transient changes of the electrical properties of the active components when exposed to these sources of radiation. The changes in the electrical characteristics can result in degradation of circuit performance or device failure. Furthermore, in a pulsed radiation environment, radiation induced photo currents can lead to transient circuit upsets.

This report summarizes the results of the Oak Ridge National Laboratory (ORNL) Monte Carlo Adjoint Shielding code system - MASH v1.0' calculations designed to estimate the dose to the critical electronics components of an idealized spaced based weapon platform from neutron and gamma-ray radiation emanating from a thermonuclear weapon detonation. The weapon platform was modeled with a full compliment of kinetiv kill vehicles (KKVs) and also in various stages of limited engagement (multiple KKVs launched). The MASH calculations modeled several source/platform geometry configurations, obtaining results for multiple distances and weapon detonation positions relative to the platform. The purpose of this study is to demonstrate the merits of the MASH code system in estimating dose and shielding factors for spaced based assets. 
The remainder of this report provides a discussion on the details of the weapon platform and kinetic kill vehicle design in Section 2.0, and an overview of the application of the MASH v1.0 code system methodology to nuclear weapon radiation threats in Section 3.0. The discussions of the results are presented in Section 4.0, and conclusions and recommendations are presented in Section 5.0. 


\subsection{CALCULATIONAL MODEL OF THE SPACE BASED INTERCEPTOR (SBI) WEAPON PLATFORM}

The weapon platform model used in this study was used previously in the ORNL Shield Optimization Program ${ }^{2}$ of the Strategic Defense Initiative (SDI) and is not proposed for deployment. The platform was "designed" by the ORNL staff on the basis of space weapon system requirements alluded to in documentation on SDI space weapon-sensor architecture requirements. Design details not relevant to the dose calculations have been omitted or purposely neglected in order to optimize the computational effort.

\section{Description}

The ORNL Space Based Interceptor (SBI) weapon platform, shown in Figure 1, is a cylindrical shell comprised of two Interceptor-Fuel Tank (IFT) modules connected by a Command, Control, and Communications $\left(\mathrm{C}^{3}\right)$ bay. Each IFT module contains five launch tube-Kinetic Kill Vehicle (KKV) assemblies and four fuel tanks. The platform has an overall length of $4.27 \mathrm{~m}$ and a diameter of $1.63 \mathrm{~m}$. An interior view of the platform showing the orientation of the KKV launch tubes and fuel tanks is given in Figure 2. Fuel storage is required for maneuvering the platform to avoid collisions with space debris, evading enemy kill vehicles and Kinetic Energy Weapon (KEW) projectiles, and positioning the platform during engagement.

Power is supplied to on-board electronic and electrical circuits by two solar panels, one on each side of the platform. These are shown in Figure 1 in the deployed position. During conflict, the panels may be folded along the top of the platform to reduce the cross-sectional area of the SBI that is exposed to attack by enemy weapons. A shield to protect the SBI against ground based laser attack covers the surfaces of the IFT and $C^{3}$ bays that are exposed to the earth. A single antenna, mounted on the top of the platform, provides communication with the reconnaissance/surveillance and battle management satellites. Although only one antenna is included in the model, it is recognized that other antennae and sensors may also exist on an actual platform design.

Figure 3 depicts the $C^{3}$ bay. The electronic systems are housed in two concentric, thin walled ring shaped containers. In the center is a box for housing "critical" or sensitive components. The rationale for designing the $\mathrm{C}^{3}$ bay in this manner allows components that are insensitive to radiation to be mounted in the outer ring while components more sensitive to radiation may be placed in the inner ring or the central box. Allowance has been made for additional local shielding to be placed in the spaces between the outer and inner rings, increasing the radiation protection of critical or sensitive components.

A prototypic kinetic kill vehicle is shown in Figure 4. The main components of the weapon are the warhead, sensors and computers (for guiding the interceptor to the target), fuel, and the rocket motor. Figure 5 shows the KKVs mounted in the launch tubes of the IFT. Other systems that may be essential in an SBI weapon platform, i.e., thermal control equipment, etc., were not included in the calculational model. The principal concern here 
Command, Control, \& Communications

Antenna Instrument Bay

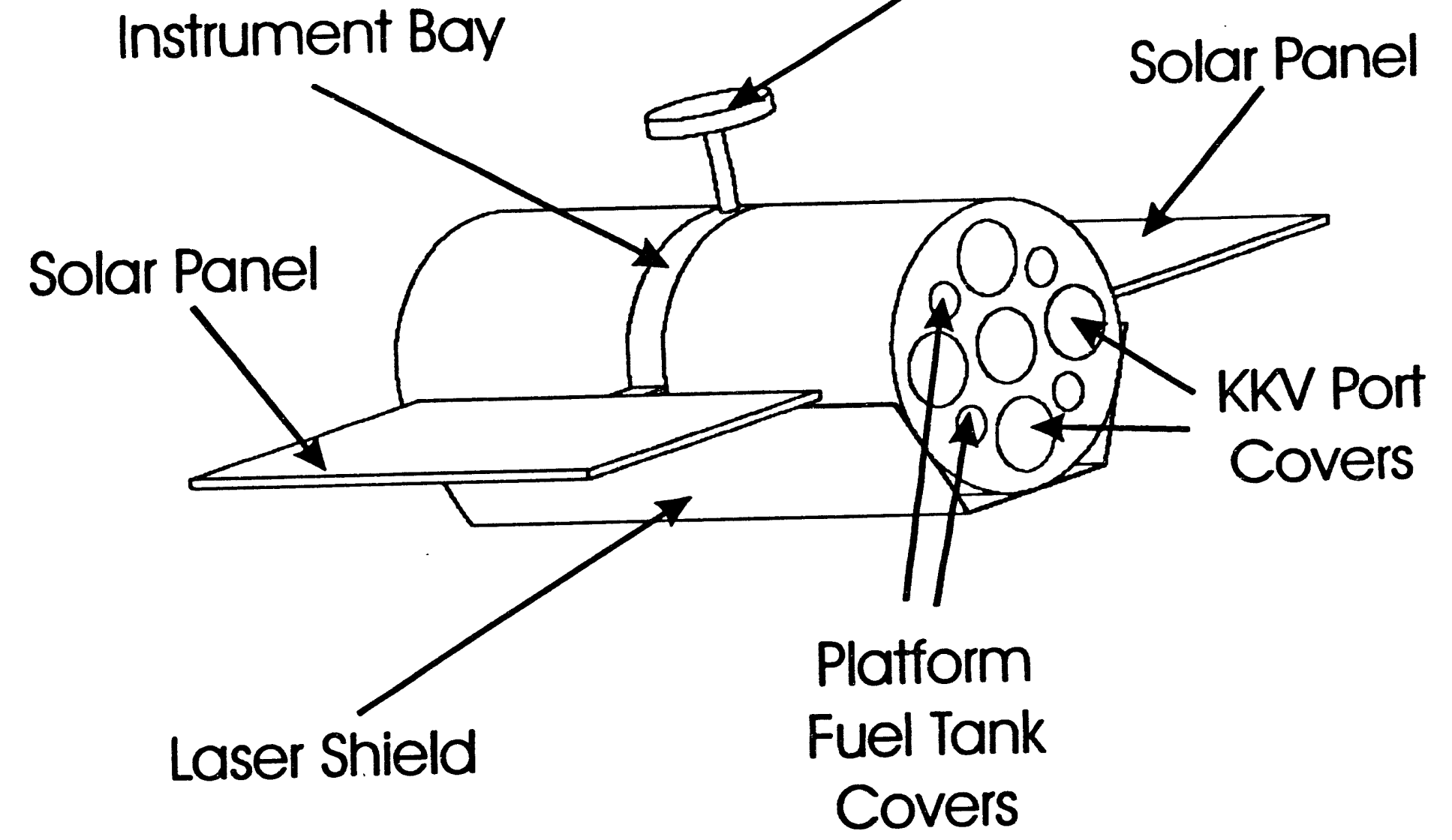

Figure 1. Schematic Diagram Illustrating the Calculational Model of the Spaced Based Interceptor Weapon Platform 
Command, Control, \& Communications

Antenna Instrument Bay

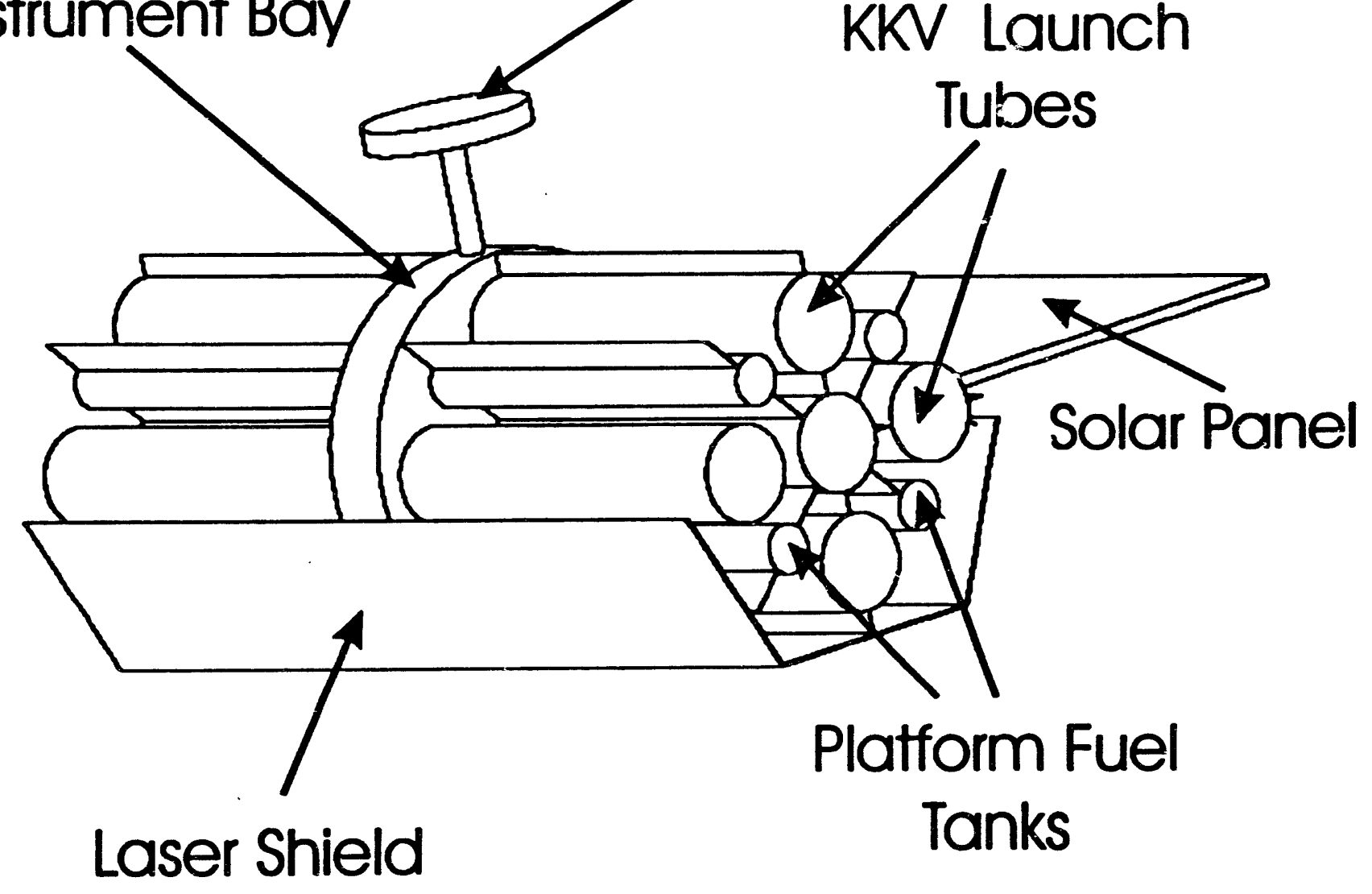

Figure 2. Interior view of the Spaced Based Interceptor Weapon Platform Showing Launch Tube and Fuel Tank Clusters 
Electronic

Instrument

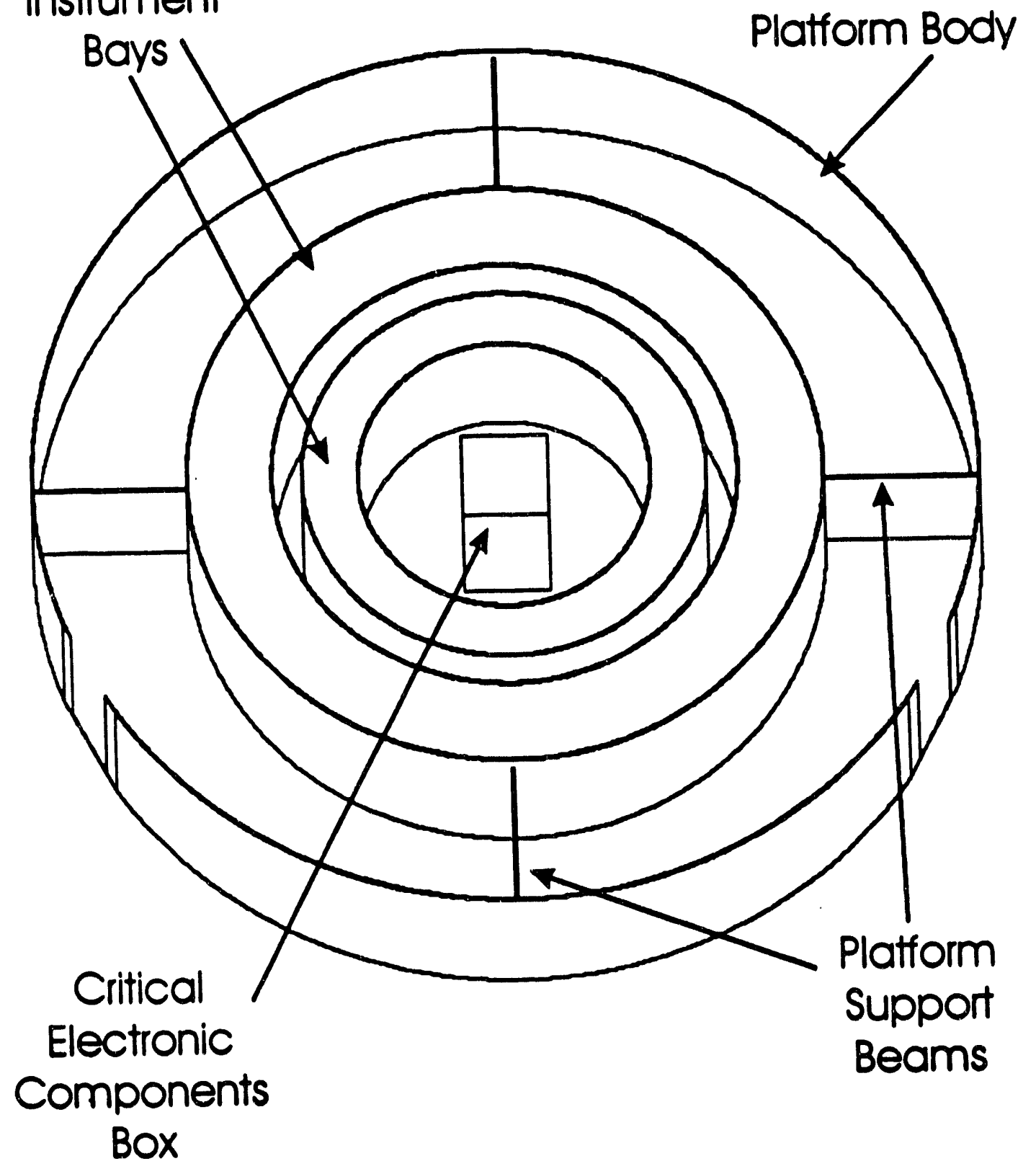

Figure 3. Schematic Diagram of the Spaced Based Interceptor Weapon Platform Command, Control, and Communications $\left(C^{3}\right)$ Instrument Bay 

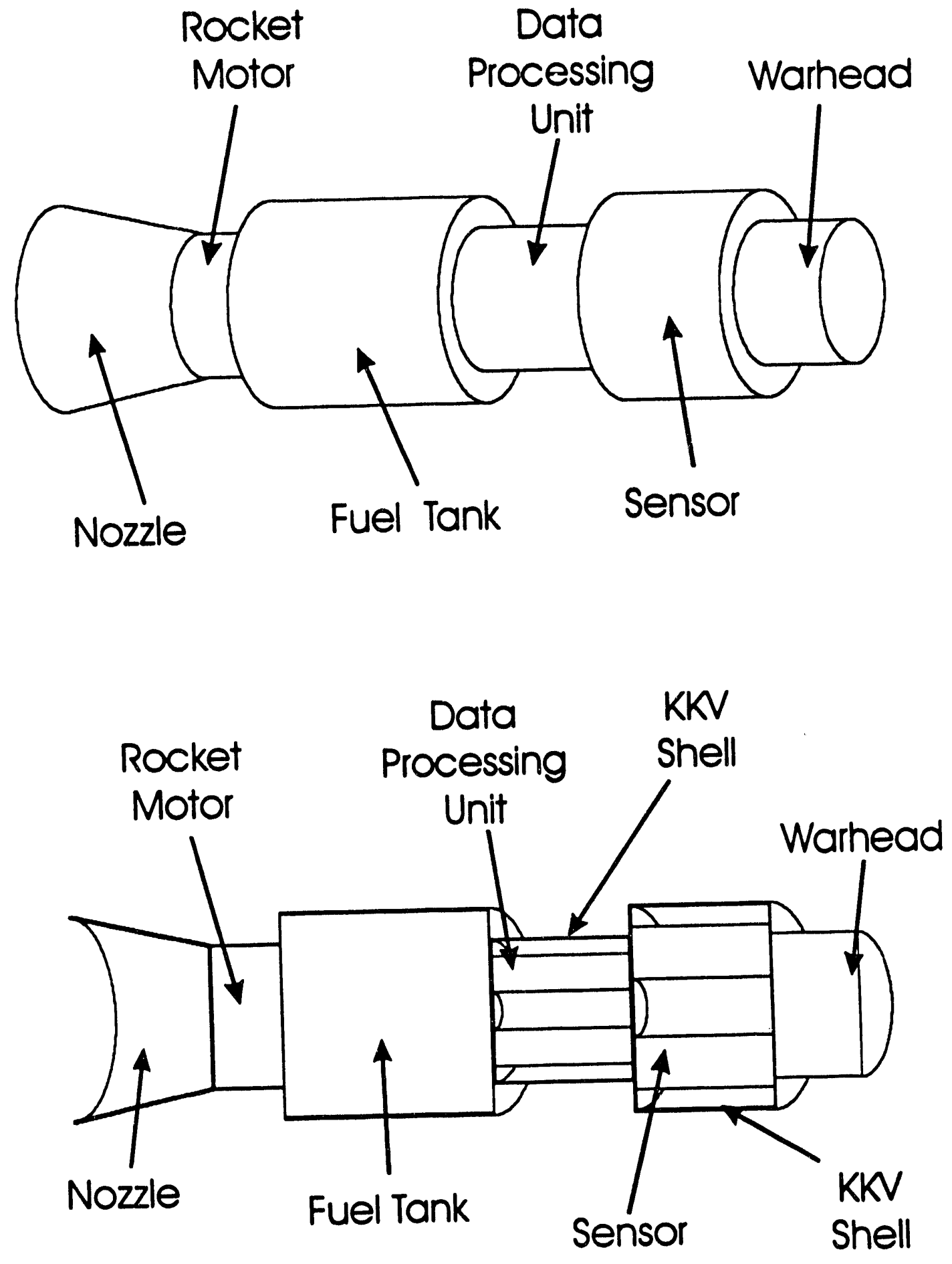

Figure 4. Schematic Diagram of the Spaced Based Interceptor Weapon Platform Kinetic Kill Vehicle 
Command, Control, \& Communications Instrument Bay

\section{Antenna}

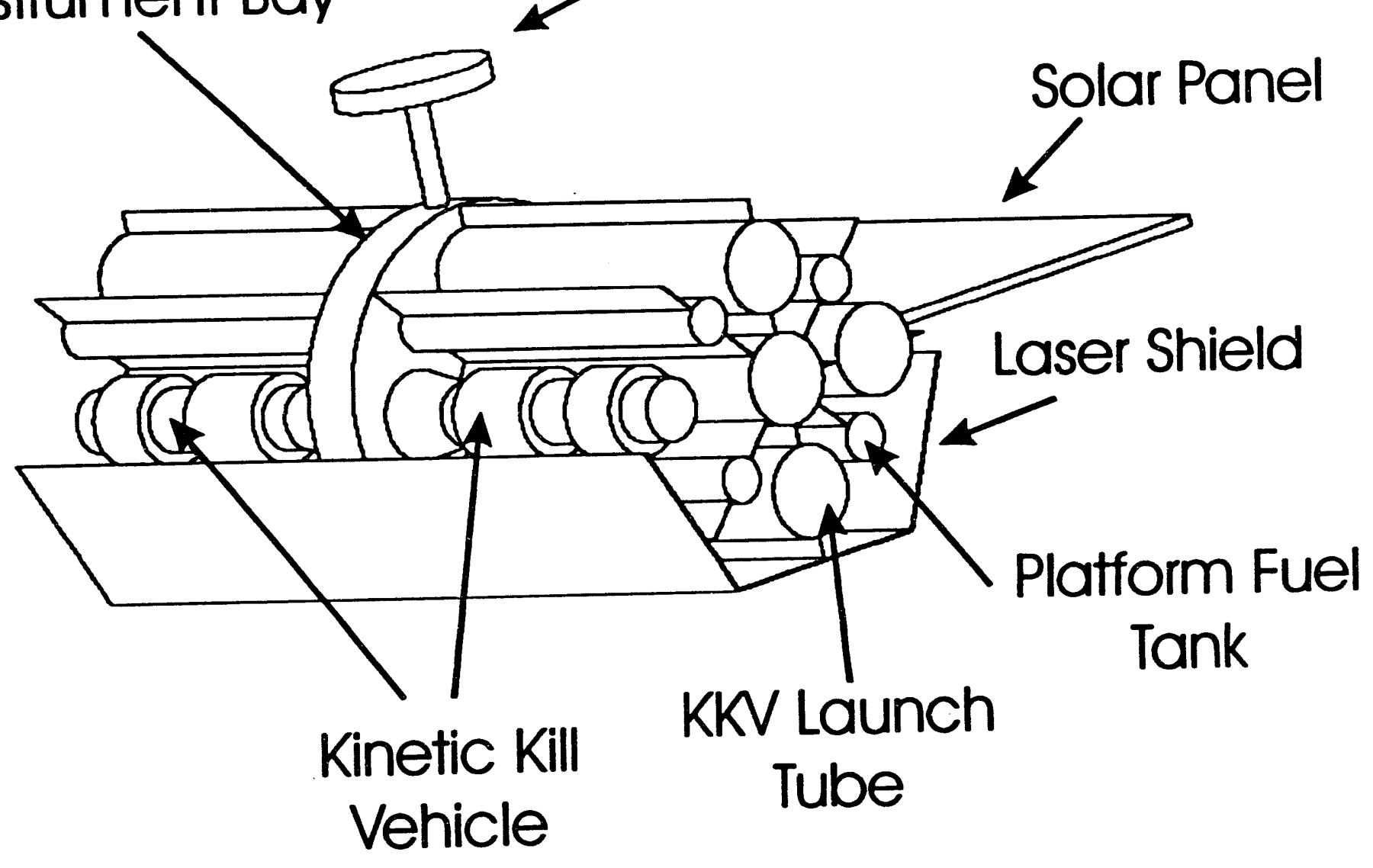

Figure 5. Schematic Diagram Illustrating the Kinetic Kill Vehicles Inside the Spaced Based Interceptor Weapon Platform Launch Tubes 
was to represent subsystems that are most sensitive to radiation damage and essential to the wartime mission.

\section{Details of the SBI Weapon Platform and Interceptors}

A complete list of the material compositions of the platform components and KKVs is given in Tables 1 and 2, respectively. The SBI platform structure, structural support members, $\mathrm{KKV}$ launch tubes, $\mathrm{C}^{3}$ bay, and fuel tanks were "constructed" with $0.32 \mathrm{~cm}$-thick aluminum. One interceptor launch tube is on the central axis of the IFT module and the remaining four are placed $1.571 \mathrm{rad}$ (90 degrees) to each other on a $0.51 \mathrm{~m}$ radius from the centerline of the IFT to the axis of the tube. The $1.98 \mathrm{~m}$-long KKV launch tubes have an inner radius of $0.21 \mathrm{~m}$. The $1.97 \mathrm{~m}$-long by $0.2032 \mathrm{~m}$ diameter fuel tanks are on the same radius and located alternately with the launch tubes." The fuel was taken to be hydrazine having a density of $1.0 \mathrm{~g} / \mathrm{cm}^{3}$. The quantity of fuel was arbitrarily chosen to maintain the overall weight of the fully loaded platform $(\approx 3000 \mathrm{~kg})$. The launch tubes and fuel tanks are connected to the IFT assembly and to each other by $0.32 \mathrm{~cm}$-thick aluminum structural supports.

The central $\mathrm{C}^{3}$ bay has an axial dimension of $0.31 \mathrm{~m}$. The radial thickness of the outer shell is $0.15 \mathrm{~m}$ (inner radius $=0.55 \mathrm{~m}$ ) and the inner shell has a radial thickness of 0.10 $\mathrm{m}$ (inner radius $=0.21 \mathrm{~m}$ ). The central box has cross-sectional dimensions of $0.15 \mathrm{~m}$ by 0.15 $\mathrm{m}$ and has an overall axial dimension of $0.298 \mathrm{~m}$. The solar panels are $3.41 \mathrm{~m}$-long, 1.71 $\mathrm{m}$-wide and $0.05 \mathrm{~m}$-thick and have an active area of $11.7 \mathrm{~m}^{2}$. The KKVs are $1.97 \mathrm{~m}$-long and have a maximum radius of $0.20 \mathrm{~m}$.

The laser shield is a thin ( $0.01 \mathrm{~m}$-thick) carbon layer. It is recognized that this shield is too thin to provide adequate protection against intense laser attack. It is included only for providing first order estimates of its radiation shielding effectiveness. Kinetic energy weapon shielding has been omitted to obtain data on the radiation response of components and surface materials and hardening requirements for the platform itself, and because there is some uncertainty in the location of these shields, i.e., directional versus full coverage. 
Table 1. Material Compositions for the SBI Weapon Platform.

\begin{tabular}{|c|c|}
\hline Component & Material \\
\hline Solar Panel & Beryllium-Silicon" \\
\hline Solar Panel Connectors & Aluminum \\
\hline Antenna Support & Aluminum \\
\hline Antenna & Aluminum \\
\hline Laser Shield & Graphite \\
\hline Platform Hull & Aluminum \\
\hline $\mathrm{C}^{3}$ Bay Critical Components Box Housing & Aluminum \\
\hline$C^{3}$ Bay Critical Components Box & Silicon $^{b}$ \\
\hline $\mathrm{C}^{3}$ Bay Critical Components Bay Walls & Aluminum \\
\hline Inner Circular Instrument Bay & Silicon ${ }^{b}$ \\
\hline Inner Circular Instrument Bay Wall & Aluminum \\
\hline Outer Circular Instrument Bay & Silicon $^{b}$ \\
\hline Outer Circular Instrument Bay Wall & Aluminum \\
\hline Circular Instrument Bay Supports & Aluminum \\
\hline KKV Tubes & Aluminum \\
\hline Fuel Tanks & Aluminum \\
\hline Fuel & Hydrazine $\left(\mathrm{N}_{2} \mathrm{H}_{4}\right)$ \\
\hline Platform Support & Aluminum \\
\hline KKV Tube Caps & Aluminum \\
\hline
\end{tabular}

$90 \%$ Beryllium - 10\% Silicon (at 50\% Density)

'Silicon at $20 \%$ Density 
Table 2. Material Compositions for the SBI Weapon Platform Kinetic Kill Vehicles (KKVs).

\begin{tabular}{|c|c|}
\hline Component & Moterial \\
\hline Nozzle & Graphite \\
\hline Motor Housing & Aluminum \\
\hline KKV Motor & Stainless Steel ${ }^{\circledR}$ \\
\hline Fuel Tank & Aluminum \\
\hline Fuel & Hydrazine $^{b}\left(\mathrm{~N}_{2} \mathrm{H}_{4}\right)$ \\
\hline Computer Housing & Aluminum \\
\hline Computer & Silicon $^{\mathfrak{c}}$ \\
\hline Sensor Housing & Aluminum \\
\hline Sensor & Silicon $^{\mathfrak{c}}$ \\
\hline KKV Warhead & Stainless Steel \\
\hline
\end{tabular}

'Stainless Steel at $15 \%$ Density

${ }^{b}$ Hydrazine at $25 \%$ Density

'Silicon at $20 \%$ Density 


\subsection{MASH V1.0 CALCULATIONAL TECHNIQUES}

\subsection{Background}

The MASH v1.0 code system was developed at ORNL to analyze the nuclear hardening capabilities of $U$. S. and foreign ground force systems for prompt radiation from a nuclear weapon detonation. MASH calculates the neutron and gamma-ray environments and radiation protection factors for armored vehicles, structures, and other shielded assemblies of interest to DoD. The nuclear hardening (shielding effectiveness) can be characterized for both personnel and electronic equipment as a function of weapon parameters (yield, height-of-burst, source-to-target range, etc.) and the orientation and configuration of the target for both tactical and strategic weapon laydowns.

For prompt radiation environments (on the ground), MASH v1.0 has been extensively benchmarked through comprehensive comparisons with measured data obtained at the Army Pulsed Radiation Facility (APRF) at Aberdeen Proving Ground, Marylend. Several experimental configurations have been studied including, the Soviet Armored Infantry Fighting Vehicle (BMP-1), the U.S. Abrams Tank (Version XM-1 and M1A1), and two steel-shielded assemblies: the Radiological Test Configuration (RTK) ${ }^{3}$ and the Two-Meter Box Test-Bed Assembly. ${ }^{4-6}$ For the BMP, XM-1, and M1A1 armored vehicles, the purpose of the measurements was to determine the neutron and gamma-ray reduction factors for the vehicle armor. For the steel-shield assemblies, particularly the two-meter box, the objective was to compile an extensive data base of measured neutron and gamma-ray differential energy spectra and dose data for evaluating the full range of capabilities of the MASH code system in reproducing the measurements. Additionally, MASH has been used to calculate crew protection factors for the U.S. $\mathrm{M} 60 \mathrm{Al}^{7}$ and crew and electronic component protertion factors for the U. S. M1A1 and M1A2 Abrams Main Battle Tanks in an initial radiation environment.

MASH v1.0 is the reference code of choice as stated in the recent update to the U. S. Army's Qualified Research Requirements (QRR) for all U. S. armored vehicle prompt radiatic.ı nuclear vulnerability calculations. Furthermore, MASH v1.0 has been adopted by the North Atlantic Treaty Organization (NATO) as the reference code for all (NATO and non-NATO) armored vehicle prompt radiation nuclear vulnerability calculations.

The MASH v1.0 calculational technique employs a GRTUNCL-DORT ${ }^{8}$ forward discrete ordinates calculation to determine the neutron and gamma-ray fluence on a coupling surface surrounding the vehicle or shielded structure and a MORSE ${ }^{9}$ adjoint Monte Carlo calculation to determine the dose importance of the surface fluence. MASH then utilizes the Detector Response Code (DRC) ${ }^{1}$ to fold the fluence together with the dose importance to yield the desired detector response(s). The general structure of a typical MASH v1.0 calculation is shown in Figure 6. MASH v1.0 was specifically designed to calculate the neutron and gamma-ray radiation environments and shielding protection factors of vehicles, structures, trenches, and other shield configurations. Consequently, the SBI weapon platform represents a realistic test problem for demonstrating the applicability of the MASH v1.0 code system to space based asset shielding design and analysis. 


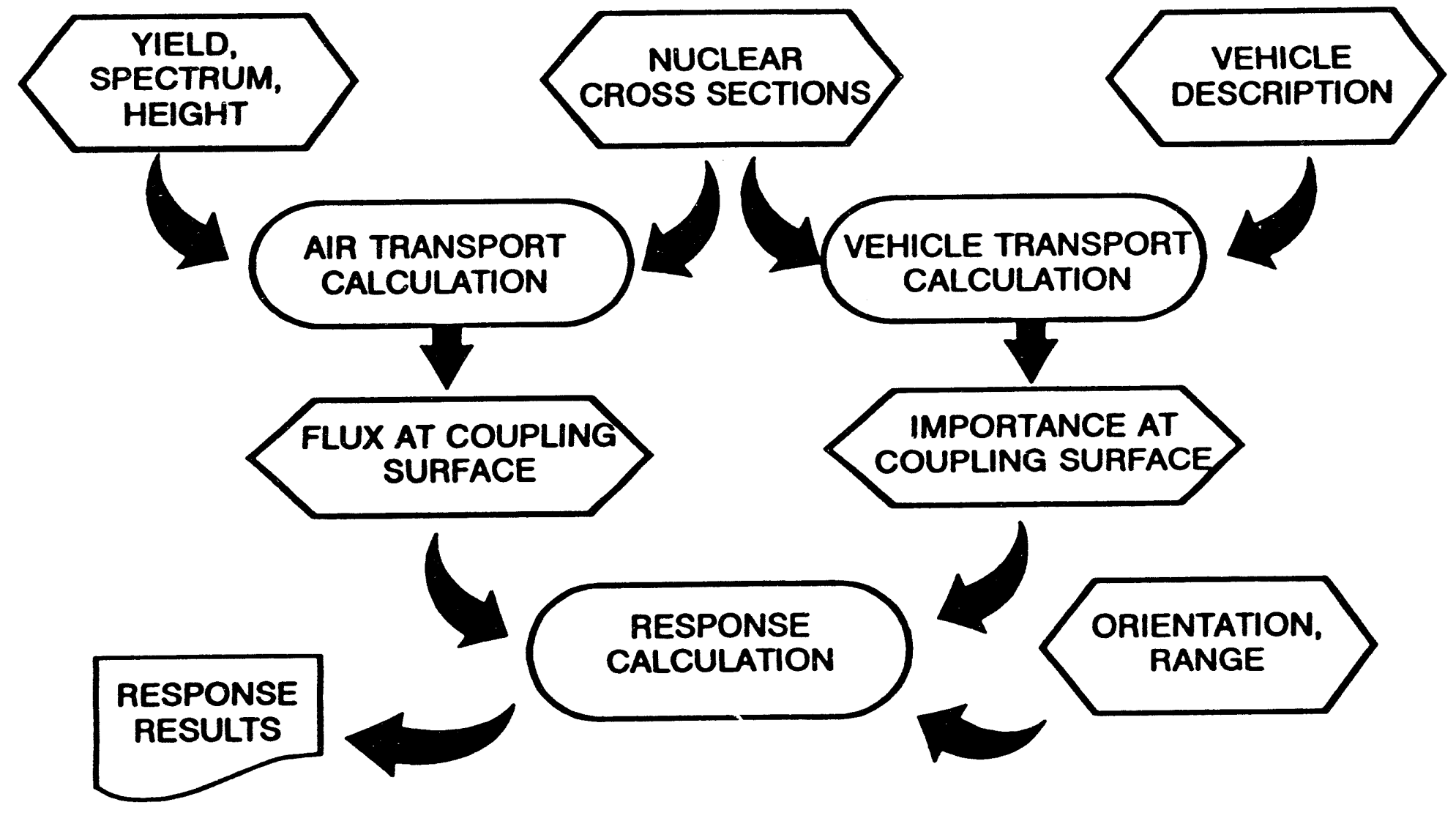

Figure 6. General Flow Diagram of the MASH v1.0 Code System Applied to a Typical Prompt Radiation Analysis of a Target Vehicle. 


\subsection{Definition of Protection and Reduction Factors}

Two quantities that are indicative of the ability of a vehicle to protect its crew or electronic equipment from penetrating nuclear radiation are protection factors (PFs) and reduction factors (RFs). The protection factors are more useful in the characterization of the vehicle shielding, whereas the reduction factors are more useful for comparisons with experimental data.

The neutron protection factor considers only the incident radiation field due to neutrons, scattered or unscattered, and secondary gamma-ray radiation arising from neutron - gamma-ray $(n, \gamma)$ reactions with the vehicle. Similarly, the gamma-ray protection factor treats only that incident radiation resulting from gamma rays produced by prompt Ession and extra-vehicle neutron - gamma-ray ( $n, \gamma)$ reactions (air and ground). Because detector systems are unable to discern the origin of the gamma rays (i.e. source, air secondary gamma ray, vehicle secondary gamma ray, etc.) contributing to the in-vehicle dose, it is anticipated that the calculated reduction factors will be more easily compared with experimental measurements than the protection factors. The definitions of the parameters and protection factors used in DRC to characterize the effectiveness of the vehicle shields are given in Figure 7. It should be noted that the definitions of the protection factors and reduction factors are independent of the response function (i.e. tissue dose, silicon dose, etc.) used in the analysis.

\subsection{Radiation Environment}

The thermonuclear weapon detonation in the upper atmosphere was modeled in the GRTUNCL and DORT codes to determine the radiation environment from which the fluence on the coupling surface could be obtained. GRTUNCL calculates the uncollided component of the fluence and DORT calculates the scalar and directional fluences of the collided component. All three components of the fluence are processed through VISTA 1 a Variable Input Source Transformation and Assembly code to obtain the fluence on the coupling surface to be folded in DRC.

The thermonuclear weapon neutron source and prompt fission gamma source were obtained from the DNA Defense Applications Broad-group Library (DABL69) 69 group $(46 n / 23 \gamma)$ cross-section library. ${ }^{10}$ Table 3 lists the thermonuclear weapon neutron leakage spectrum (normalized to unity), and Table 4 presents the prompt fission gamma-ray leakage spectrum (normalized to unity). Implementing the sources in this manner allows the fluence and dose results to be obtained per source neutron or gamma ray. Information on the weapon size (number of kilotons), absolute yield (particles per kiloton), and neutron to gamma-ray ratio will allow the results to be calculated for any thermonuclear weapon.

The radiation environment cylindrical geometry model for the thermonuclear weapon detonation utilized 40 radial intervals and 80 axial intervals in an r-z model. This mesh modeled a $50 \mathrm{~km}$ by $50 \mathrm{~km}$ radiation environment. The source was set at the center of the radial and axial mesh $(r=0.0, z=0.0)$. The radiation environment model utilized a modified 

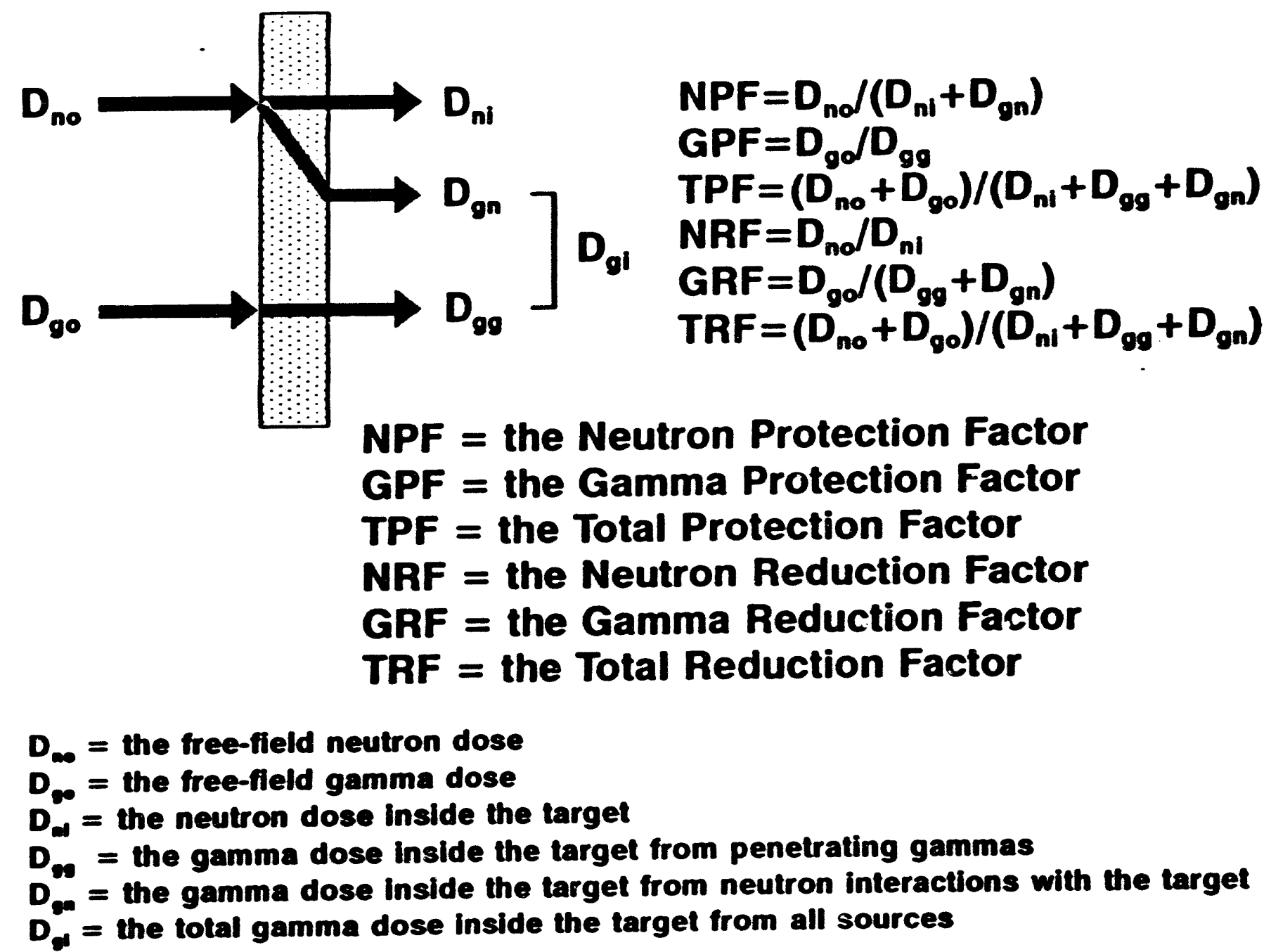

Figure 7. Definitions of Neutron, Gamma-Ray, and Total Protection Factors and Reduction Factors Used to Characterize Material Shielding Effectiveness 
Table 3. DABL69 46 Energy Group Structure, Normalized Thermonuclear Weapon Detonation Neutron Source Spectrum (Number of Neutrons per Energy Bin), and DABL69 Silicon Kerma Response Function $\left(\mathrm{cGy} \cdot \mathrm{cm}^{2}\right)$ Used in the MASH v1.0 Analysis.

\begin{tabular}{|c|c|c|c|c|c|c|c|}
\hline $\begin{array}{c}\text { Group } \\
\text { No. }\end{array}$ & $\begin{array}{l}\text { Upper } \\
\text { Energy } \\
\text { (eV) }\end{array}$ & $\begin{array}{c}\text { Thermonuclear } \\
\text { Weapon } \\
\text { Source }\end{array}$ & $\begin{array}{c}\text { DABL69 } \\
\text { Silicon } \\
\text { Kerma }\end{array}$ & $\begin{array}{c}\text { Group } \\
\text { No. }\end{array}$ & $\begin{array}{l}\text { Upper } \\
\text { Energy } \\
\text { (eV) }\end{array}$ & $\begin{array}{c}\text { Thermonuclear } \\
\text { Weapon } \\
\text { Source }\end{array}$ & $\begin{array}{l}\text { DABL69 } \\
\text { Silicon } \\
\text { Kerma }\end{array}$ \\
\hline : & $1.9640+07^{\circ}$ & $0.000+00$ & 1.4837 .09 & 24 & $8.2085+05$ & $1.240-02$ & $5.5232-11$ \\
\hline 2 & $1.6905+07$ & $0.000+00$ & 1.2551 .09 & 25 & $7.4274+05$ & $1.640-02$ & $3.4906-11$ \\
\hline 3 & $1.4: 18+07$ & $1.890-02$ & $1.2058-09$ & 26 & $6.3927+05$ & $1.410-02$ & $5.1424-11$ \\
\hline 4 & $1.4191+07$ & $9.340-03$ & $1.1890-09$ & 27 & $5.5023+05$ & $4.220-02$ & 3.2799 .11 \\
\hline 5 & $1.3840+07$ & $2.660-02$ & 1.1783 .09 & 28 & $3.6883+0.5$ & 2.830 .02 & $2.8511-11$ \\
\hline 6 & $1.2523+07$ & $1.670-02$ & $1.1596-0$ & 29 & $2.4724+05$ & $2.090-02$ & $3.3153-11$ \\
\hline 7 & $1.2214+07$ & $1.690-02$ & $1.1207-09$ & 30 & $1.5764+05$ & $1.160-02$ & $1.8416-12$ \\
\hline 8 & $1.1052+07$ & $1.240-02$ & $1.0282-09$ & 31 & $1.1109+05$ & $1.110-01$ & $2.7739-12$ \\
\hline 9 & $1.0000+07$ & $7.480-03$ & $8.8764-10$ & 32 & $5.2475+04$ & 3.540 .02 & $1.4960-12$ \\
\hline 10 & $9.0484+06$ & $6.820-03$ & $7.7844-10$ & 33 & $3.4307+04$ & $1.860-02$ & $9.7846-13$ \\
\hline 11 & $8.1873+06$ & $6.780-03$ & $7.0174-10$ & 34 & $2.4788+04$ & $5.680-03$ & $8.0146-13$ \\
\hline 12 & $7.4082+06$ & $1.030-02$ & $4.5420-10$ & 35 & $2.1875+04$ & $9.260-02$ & $5.9415-13$ \\
\hline 13 & $6.3763+06$ & $1.810-02$ & $2.3179-10$ & 36 & $1.0595+04$ & $1.160-01$ & $2.9900-13$ \\
\hline 14 & $4.9658+06$ & $3.620-03$ & 1.8923-10 & 37 & $3.3546+03$ & $7.380-02$ & $1.0632-13$ \\
\hline 15 & $4.7237+06$ & $1.240-02$ & $1.5273-10$ & 38 & $1.2341+03$ & $2.320-02$ & $4.5429-14$ \\
\hline 16 & $4.0657+06$ & $2.600-02$ & $1.0671-10$ & 39 & $5.8495+02$ & $1.300-02$ & $2.3725-14$ \\
\hline 17 & $3.0119+06$ & $2.370-02$ & $1.0988-10$ & 40 & $2.7536+02$ & $7.340-03$ & $9.4092-15$ \\
\hline 18 & $2.3852+06$ & $3.750-03$ & $9.6067-11$ & 41 & $1.0130+02$ & $1.900-03$ & $4.2320-15$ \\
\hline 19 & $2.3096+06$ & $2.560-02$ & $9.7315-11$ & 42 & $2.9023+01$ & $0.000+00$ & 3.3337-15 \\
\hline 20 & $1.8268+06$ & $3.620-02$ & $7.6827-11$ & 43 & $1.0677+01$ & $0.000+00$ & $4.4488-15$ \\
\hline 21 & $1.4227+06$ & $2.820-02$ & $4.6333-11$ & 44 & $3.0590+00$ & $0.000+00$ & $7.3573-15$ \\
\hline 22 & $1.1080+06$ & $2.320-02$ & $5.1293-11$ & 45 & $1.1253+00$ & $0.000+00$ & $1.2185-14$ \\
\hline \multirow[t]{2}{*}{23} & $9.6164+05$ & $2.230-02$ & $5.6642-11$ & 46 & $4.1399-01$ & $0.000+00$ & $5.1798-14$ \\
\hline & & & & & $1.0000-05$ & & \\
\hline
\end{tabular}

'Response Function units per neutron. 
Table 4. DABL69 23 Energy Group Structure, Normalized Thermonuclear Weapon Detonation Gamma-Ray Source Spectrum (Number of Gamma Rays per Energy Bin), and DABL69 Silicon Kerma Response Function ( $\mathrm{cGy} \cdot \mathrm{cm}^{2}$ ) Used in the MASH v1.0 Analysis.

\begin{tabular}{|c|c|c|c|c|c|c|c|}
\hline $\begin{array}{c}\text { Group } \\
\text { No. }\end{array}$ & $\begin{array}{l}\text { Upper } \\
\text { Energy } \\
(\mathrm{eV})\end{array}$ & $\begin{array}{c}\text { Thermonuclear } \\
\text { Weapon } \\
\text { Source }\end{array}$ & $\begin{array}{l}\text { DABL69 } \\
\text { Silicon } \\
\text { Kerma }\end{array}$ & $\begin{array}{c}\text { Group } \\
\text { No. }\end{array}$ & $\begin{array}{l}\text { Upper } \\
\text { Energy } \\
(\mathrm{eV})\end{array}$ & $\begin{array}{l}\text { Thermonuclear } \\
\text { Weapon } \\
\text { Source }\end{array}$ & $\begin{array}{l}\text { DABL69 } \\
\text { Silicon } \\
\text { Kerma }\end{array}$ \\
\hline 1 & $2.00+07$ & $0.000+00$ & $5.5811-09$ & 13 & $1.50+06$ & $1.430-01$ & $5.3117-10$ \\
\hline 2 & $1.40+07$ & $8.250-06$ & 3.9449 .09 & 14 & $1.00+06$ & $1.320-01$ & $3.8809-10$ \\
\hline 3 & $1.20+07$ & $8.250-06$ & $3.3166-09$ & 15 & $7.00+05$ & $1.500-01$ & $2.7003-10$ \\
\hline 4 & $1.00+07$ & $1.340-04$ & $2.6901-09$ & 16 & $4.50+05$ & $1.110-01$ & $1.7745 \cdot 10$ \\
\hline 5 & $8.00+06$ & $3.020-04$ & $2.2304-09$ & 17 & $3.00+05$ & $1.310-01$ & $1.0327-10$ \\
\hline 6 & $7.00+06$ & $9.080-04$ & $1.9503-09$ & 18 & $1.50+05$ & $4.790-02$ & $7.0047-11$ \\
\hline 7 & $6.00+06$ & $2.730-03$ & $1.6851-09$ & 19 & $1.00+05$ & $3.010-02$ & $8.2570-11$ \\
\hline 8 & $5.00+06$ & $8.190-03$ & $1.4210-09$ & 20 & $7.00+04$ & $2.580-02$ & $1.5150-10$ \\
\hline 9 & $4.00+06$ & $2.460-02$ & $1.1557-09$ & 21 & $4.50+04$ & $1.580-02$ & $3.4811-10$ \\
\hline 10 & $3.00+06$ & $2.700-02$ & $9.6274-10$ & 22 & $3.00+04$ & $1.070-02$ & $8.2986-10$ \\
\hline 11 & $2.50+0.6$ & $4.690-02$ & $8.2914 \cdot 10$ & 23 & $2.00+04$ & $1.080-02$ & $2.6565-09$ \\
\hline 12 & $2.00+0.5$ & $8.120-02$ & $6.8711-10$ & & $1.00+04$ & & \\
\hline
\end{tabular}

'Response Function units per gamma ray. 
$\mathrm{S}_{8}$ (240 direction) quadrature, a $\mathrm{P}_{5}$ Legendre expansion of the cross sections, the DABL69 cross-section library and one mixture of air at a reduced density to simulate the upper atmosphere.

\subsection{The SBI Weapon Platform Geometry Model}

The SBI weapon platform described in Section 2.0 and shown schematically in Figures 1-5 was modeled in the MORSE component of the MASH code system using the GIFT ${ }^{11,12)}$ geometry package. Two-hundred forty-three body descriptors and two-hundred forty-three regions were required to describe the platform. Table 5 lists the volumes, material compositions, and masses of the weapon platform components. The SBI weapon platform is currently configured to have a mass of $2030.15 \mathrm{~kg}$, not including the ten KKVs that it will carry. There is currently no additional internal shielding in place to reduce the effects of natural and nuclear weapon radiation environrnents on the electronic components. The electronics are represented as homogeneous silicon distributed throughout the instrument bays at theoretical or reduced density (to account for the distributions of sub-components) depending on the location in the platform.

Table 6 lists the volumes, material components, and masses of the KKV interceptors depicted in Figure 4. Each KKV has a mass of $69.16 \mathrm{~kg}$, so when the platform is deployed and fully loaded, its total mass is $2721.75 \mathrm{~kg}$. The KKV sensors and computers are initially unshielded in order to assess their vulnerability to the incident radiation. These components will be hardened using reentry vehicle hardening technology to assure survivability in severe nuclear radiation environments.

Three different geometry models of the SBI weapon platform were analyzed with the MASH code system. One model represents the weapon platform in a fully loaded condition (all KKVs present), and the other two models represent the weapon platform after a partial engagement (some KKVs launched). The first partial engagement model is for the platform with the center KKVs launched from both IFT modules. The second partial engagement model is for the platform with the top and bottom KKVs launched from both IFT modules. A single detector position was chosen in the critical components box of the $\mathrm{C}^{3}$ instrument bay for the determination of the neutron and gamma-ray flux (and dose) spectra in the weapon platform. The neutron and gamma-ray silicon kerma response functions included in the DABL69 cross-section library were utilized in DRC to obtain the dose responses in the free-field and in the SBI weapon platform. Listings of the neutron and gamma-ray silicon kerma response functions are given in Tables 3 and 4 respectively.

\subsection{The SBI Weapon Platform Calculations}

The MASH calculations also utilized the reference DNA DABL69 46n/23r group cross-section library. The Monte Carlo (MORSE) calculations for the three weapon platform configurations generated and tracked 500,000 primary source particles (500 batches $/ 1000$ source particles per batch) for the $\mathrm{C}^{3}$ instrument bay critical components box detector location sampled over the 69 energy groups. An energy dependent relative importance factor 
Table 5. SBI Weapon Platform Component Volumes and Masses.

\begin{tabular}{|c|c|c|c|}
\hline Component & $\begin{array}{c}\text { Volume } \\
\left(\mathrm{cm}^{3}\right)\end{array}$ & Material & $\begin{array}{c}\text { Mass } \\
\text { (kg) }\end{array}$ \\
\hline Solar Panel & 291350.76 & Beryllium-Silicon & $552.11^{2}$ \\
\hline Solar Panel Connectors & 1524.00 & Aluminum & 4.11 \\
\hline Antenna Support & 3926.99 & Aluminum & 10.60 \\
\hline Antenna & 38484.51 & Aluminum & $17.70^{b}$ \\
\hline Laser Shield & 111929.95 & Graphite & 223.86 \\
\hline Platform Hull (2 parts) & 78969.02 & Aluminum & 213.22 \\
\hline$C^{3}$ Bay Critical Components Box Housing & 19273.98 & Aluminum & 49.34 \\
\hline$C^{3}$ Bay Critical Components Box & 6021.32 & Silicon & $2.77^{b}$ \\
\hline$C^{3}$ Bay Critical Components Bay Walls & 692.68 & Aluminum & 1.87 \\
\hline Innermost Circular Instrument Bay Wall & 1509.52 & Aluminum & 4.08 \\
\hline Inner Circular Instrument Bay & 52647.26 & Silicon & $24.22^{b}$ \\
\hline Inner Circular Instrument Bay Wall & 2090.30 & Aluminum & 5.64 \\
\hline Outer Circular Instrument Bay Wall & 2409.47 & Aluminum & 6.51 \\
\hline Outer Circular Instrument Bay & 127887.01 & Silicon & $58.83^{b}$ \\
\hline Outer Circular Instrument Bay Wall & 3290.23 & Aluminum & 8.88 \\
\hline Circular Instrument Bay Supports & & & 2.18 \\
\hline KKV Tubes (10) & 8158.08 & Aluminum & 220.27 \\
\hline Fuel Tanks (8) & 2143.30 & Aluminum & 46.30 \\
\hline Fuel & 64145.11 & Hydrazine $\left(\mathrm{N}_{2} \mathrm{H}_{4}\right)$ & 513.16 \\
\hline Platform Supports (16) & 1225.41 & Aluminum & 52.94 \\
\hline KKV Tube Caps (10) & 428.27 & Aluminum & 11.56 \\
\hline \multicolumn{3}{|c|}{ Total Mass } & 2030.15 \\
\hline
\end{tabular}

$90 \%$ Beryllium - 10\% Silicon (at 50\% Density)

Silicon at 20\% Density 
Table 6. Kinetic Kill Vehicle Component Volumes and Masses (Per KKV).

\begin{tabular}{|l|c|c|c|}
\hline \multicolumn{1}{|c|}{ Component } & $\begin{array}{c}\text { Volume } \\
\left(\mathrm{cm}^{3}\right)\end{array}$ & Material & $\begin{array}{c}\text { Mass } \\
(\mathrm{kg})\end{array}$ \\
\hline Nozzle & 2148.04 & Graphite & 4.30 \\
Motor Housing & 635.73 & Aluminum & 1.72 \\
KKV Motor & 8748.33 & Stainless Steel & $10.24^{\circ}$ \\
Fuel Tank & 2602.52 & Aluminum & 7.03 \\
Fuel & 54850.93 & Hydrazine $\left(\mathrm{N}_{2} \mathrm{H}_{4}\right)$ & $13.71^{\circ}$ \\
Computer Housing & 1224.44 & Aluminum & 3.31 \\
Computer & 9423.26 & Silicon & $4.33^{\mathrm{c}}$ \\
Sensor Housing & 1994.59 & Aluminum & 5.39 \\
Sensor & 20023.96 & Silicon & $9.21^{\mathrm{c}}$ \\
KKV Warhead & 1271.65 & Stainless Steel & 9.92 \\
\hline \hline
\end{tabular}

Stainless Steel at 15\% Density

'Hydrazine at $25 \%$ Density

Silicon at $20 \%$ Density 
was utilized over the 69 groups to increase the frequency of sampling the adjoint source particles from energy groups which have a significant effect on the dose response function. The secondary particle production probability was set to 1.0 for all regions and energy groups in the Monte Carlo calculations, and the in-group energy biasing option in MORSE was switched on. Region dependent and energy independent splitting and Russian Roulette parameters were utilized to improve the efficiency of the Monte Carlo calculations. The elemental compositions and atomic number densities used in the adjoint MORSE calculations of the SBI weapon platform configurations are given in Table 7.

\subsection{Monte Carlo Statistical Uncertainty}

Analysis of the MORSE escape history tapes in DRC for all of the weapon platform configurations yielded statistical uncertainties on the order of $\pm 12 \%$ for integral neutron fluence(dose) and $\pm 10 \%$ for total gamma-ray fluence(dose). The statistical uncertainties for the vehicle secondary gamma-ray production, i.e. vehicle $(n, \gamma)$, and the direct gamma ray plus air secondary gamma-ray production, i.e. source gamma rays + air $(n, \gamma)$, are typically $\pm 8-10 \%$, and $\pm 8-12 \%$ respectively. Spectral fluence (dose) results exhibited statistical uncertainties typically between $\pm 10 \%$ and $\pm 20 \%$ for neutron energies between $15 \mathrm{MeV}$ and $10 \mathrm{keV}$, and between $\pm 10 \%$ and $\pm 25 \%$ for gamma-ray energies between $12 \mathrm{MeV}$ and $100 \mathrm{keV}$. These energy ranges contain the energy groups in the DABL69 group structure which make significant contributions to the silicon kerma response. 
Table 7. SBI Platform and KKV Material Parameters.

\begin{tabular}{|c|c|c|c|c|c|}
\hline Materials & $\begin{array}{l}\text { Density } \\
\left(\mathrm{g} / \mathrm{cm}^{3}\right)\end{array}$ & \multicolumn{2}{|c|}{$\begin{array}{l}\text { Weight } \\
\text { Fraction }\end{array}$} & $\begin{array}{l}\text { Atomic Weight } \\
(\mathrm{g} / \mathrm{mol})\end{array}$ & $\begin{array}{l}\text { Atom Density } \\
\left(\mathrm{b}^{-1} \cdot \mathrm{cm}^{-1}\right)\end{array}$ \\
\hline Aluminum & 2.70 & 1.000 & $\mathbf{A l}$ & 26.98 & $6.027-02^{a}$ \\
\hline Silicon@ 20\% & 0.46 & 1.000 & $\mathrm{Si}$ & 28.09 & $9.865-03$ \\
\hline Hydrazine @ 25\% & 0.25 & $\begin{array}{l}0.874 \\
0.126\end{array}$ & $\begin{array}{l}\mathbf{N} \\
\mathbf{H}\end{array}$ & $\begin{array}{c}14.01 \\
1.01\end{array}$ & $\begin{array}{l}9.411-03 \\
1.882-02\end{array}$ \\
\hline Hydrazine & 1.00 & $\begin{array}{l}0.874 \\
0.126\end{array}$ & $\begin{array}{l}\mathbf{N} \\
\mathbf{H}\end{array}$ & $\begin{array}{c}14.01 \\
1.01\end{array}$ & $\begin{array}{l}3.764-02 \\
7.529-02\end{array}$ \\
\hline Beryllium-Silicon @ 50\% & 0.95 & $\begin{array}{l}0.900 \\
0.100\end{array}$ & $\begin{array}{l}\mathrm{Be} \\
\mathrm{Si}\end{array}$ & $\begin{array}{c}9.01 \\
28.09\end{array}$ & $\begin{array}{l}5.564-02 \\
2.466-03\end{array}$ \\
\hline Graphite & 2.00 & 1.000 & C & 12.01 & $1.003-01$ \\
\hline Stainless Steel @ 15\% & 1.17 & $\begin{array}{l}0.170 \\
0.017 \\
0.025 \\
0.120 \\
0.010 \\
0.658\end{array}$ & $\begin{array}{l}\mathrm{Cr} \\
\mathrm{Mn} \\
\mathrm{Mo} \\
\mathrm{Ni} \\
\mathrm{Si} \\
\mathrm{Fe}\end{array}$ & $\begin{array}{l}52.00 \\
54.94 \\
95.94 \\
58.70 \\
28.09 \\
55.85\end{array}$ & $\begin{array}{l}2.304-03 \\
2.181-04 \\
1.836-04 \\
1.441-03 \\
2.510-04 \\
8.302-03\end{array}$ \\
\hline Stainless Steel & 7.80 & $\begin{array}{l}0.170 \\
0.017 \\
0.025 \\
0.120 \\
0.010 \\
0.658\end{array}$ & $\begin{array}{l}\mathrm{Cr} \\
\mathrm{Mn} \\
\mathrm{Mo} \\
\mathrm{Ni} \\
\mathrm{Si} \\
\mathrm{Fe}\end{array}$ & $\begin{array}{l}52.00 \\
54.94 \\
95.94 \\
58.70 \\
28.09 \\
55.85\end{array}$ & $\begin{array}{l}1.536-02 \\
1.454-03 \\
1.224-03 \\
9.604-03 \\
1.673-03 \\
5.535-02\end{array}$ \\
\hline Air @ 10 $0^{-10} \%$ & $1.22-15$ & $\begin{array}{l}0.756 \\
0.232 \\
0.012\end{array}$ & $\begin{array}{l}N \\
0 \\
A r\end{array}$ & $\begin{array}{l}14.01 \\
16.00 \\
39.95\end{array}$ & $\begin{array}{l}3.965-17 \\
1.065-17 \\
2.355-19\end{array}$ \\
\hline
\end{tabular}

"Read as $6.027 \times 10^{-2}$ 


\subsection{DISCUSSION OF RESULTS}

To demonstrate the applicability of MASH for analyzing spaced based assets exposed to nuclear weapon radiation, calculations have been completed for a thermonuclear weapon detonation in space. Fluence and dose assessments were performed for the platform fully loaded, center KKVs launched, and multiple side KKVs launched. The results were obtained for the $C^{3}$ bay critical components box; for the platform at $1 \mathrm{~km}$ and $10 \mathrm{~km}$; and with the weapon detonation facing the top of the platform, facing an end of the platform, and at an angle approximately $0.785 \mathrm{rad}$ (45 degrees) to the platform. A schematic diagram of the SBI weapon platform orientations relative to the thermonuclear weapon detonation is given in Figure 8.

\subsection{Bay Critical Components Box Dose (Silicon), Protection Factor, and Reduction Factor Results}

The MASH integral fluence, dose, and protection factor and reduction factor results for the free-field and in-platform detector locations are presented in Tables 8-14. Table 8 presents the free-field fluences and doses for the thermonuclear weapon detonation and the sequence of source/weapon platform orientations. MASH integral silicon kerma dose results for the SBI weapon platform are presented for the fully loaded platform configuration, the center KKVs launched configuration, and the top and bottom KKVs launched configuration in Tables 9 through 11, respectively. Corresponding neutron and gamma-ray protection factors and reductions factors are presented in Tables 12 through 14 for the integral dose results given in Tables 9 through 11 .

The results indicate varying degrees of radiation protection for the different source/platform orientations and configurations analyzed. With respect to dose, the results indicate an approximate $1 / \mathrm{R}^{2}$ dependence as seen in the comparison of the $1 \mathrm{~km}$ and $10 \mathrm{~km}$ source distance cases in Table 8 (Free-Field) and Table 9 (In-Platform). Similar results were evidenced in the two partial engagement platform configurations (Tables 10 and 11), and therefore the $10 \mathrm{~km}$ dose results were not reported. The protection factors and reduction factors for these two source distance cases (Table 12), however, are constant since both the free-field and in-platform doses are falling off by approximately the same factor.

The dose results for the fully loaded platform (Table 9) indicate the higher dose rates are incurred in the critical components box when the source/platform orientation is at an angle other than $0.0 \mathrm{rad}$ or $1.571 \mathrm{rad}[$ e.g., $(r=1 \mathrm{~km}, z=1 \mathrm{~km})]$. The lower dose rates occur when the source is facing the top of the platform $(r=1 \mathrm{~km}, z=0 \mathrm{~km})$, or on-axis with the platform facing one set of the platform launch tubes $(r=0 \mathrm{~km}, z=1 \mathrm{~km})$. Similar dose results are seen in Table 11 for the platform configuration with the top and bottom KKVs launched. However, the results in Table 11 indicate approximately $25 \%$ to $35 \%$ less dose to the critical components box for the source positioned on-axis facing one set of KKV launch tubes $(r=0$ $\mathrm{km}, \mathrm{z}=1 \mathrm{~km}$ ) when compared to the fully loaded platform (Table 9). This is due to less secondary particle production and less scattering off of the remaining KKVs. The dose results for the platform with the center KKVs launched clearly indicate a direct line-of-sight to the 


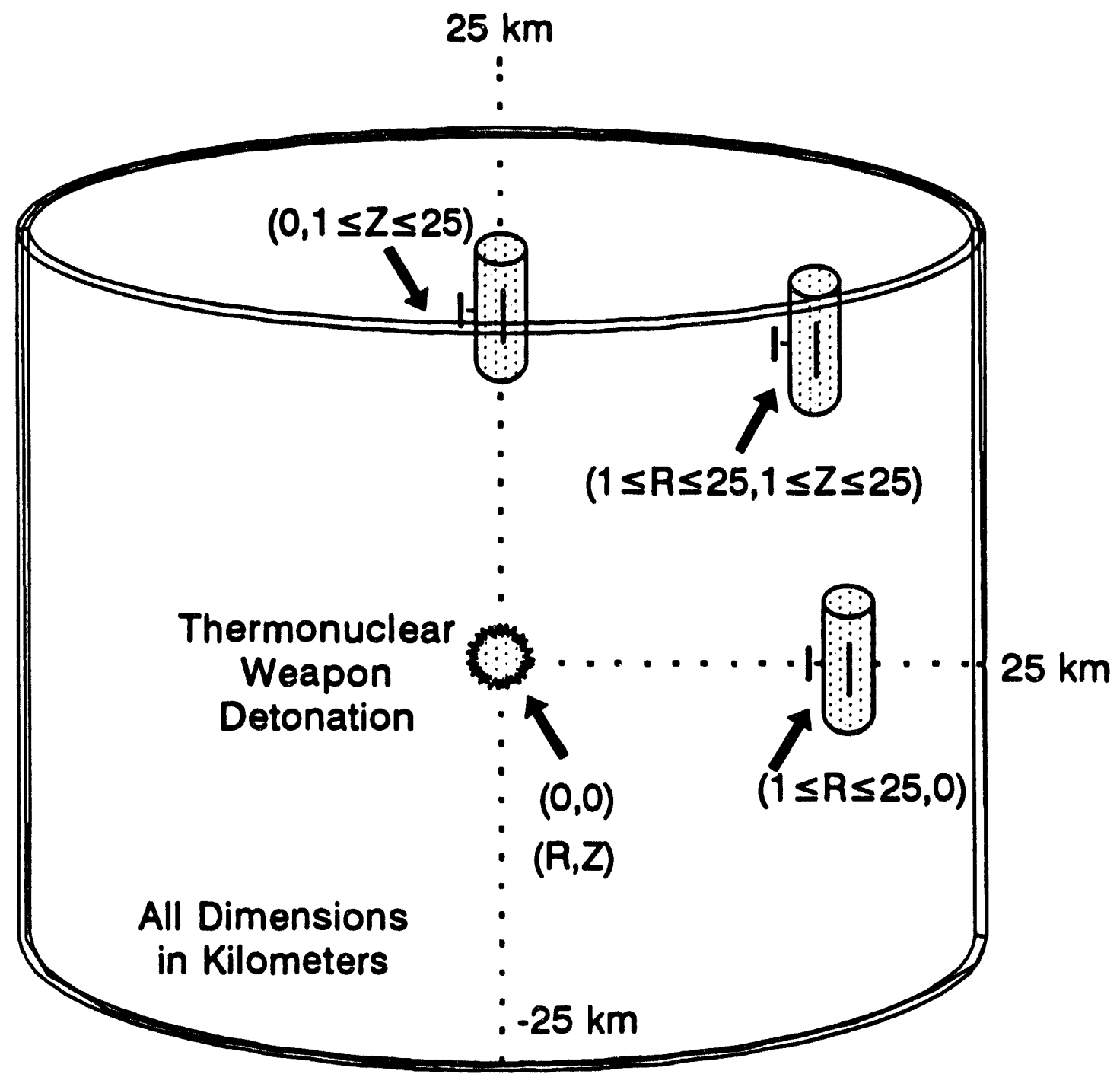

Figure 8. Schematic Diagram of the SBI Weapon Platform Orientations Relative to the Thermonuclear Weapon Detonation 
Table 8. Calculated Neutron and Gamma-Ray Free-Field Fluences and Doses for the Silicon Components in the SBI Weapon Platform $C^{3}$ Bay Critical Components Box Due to a Thermonuclear Weapon Detonation.

\begin{tabular}{|c|c|c|c|c|}
\hline & \multicolumn{2}{|c|}{ Neutron Free-Field } & \multicolumn{2}{|c|}{ Gamma-Ray Free-Field } \\
\hline $\begin{array}{l}\text { Position of Platform } \\
\text { (Relative to Source) }\end{array}$ & $\begin{array}{l}\text { Fluence } \\
\left(\mathrm{cm}^{-2}\right)\end{array}$ & $\begin{array}{l}\text { Doseb } \\
\text { (cGy) }\end{array}$ & $\begin{array}{l}\text { Fluence" } \\
\left(\mathrm{cm}^{-2}\right)\end{array}$ & $\begin{array}{l}\text { Dosec } \\
(c G y)\end{array}$ \\
\hline Radius $=1 \mathrm{~km}$. Height $=0 \mathrm{~km}$ & $7.415-12$ & $1.218-21$ & $7.404-12$ & $3.118-21$ \\
\hline Radius $=10 \mathrm{~km}$, Height $=0 \mathrm{~km}$ & 6.799 .14 & $1.095-23$ & $6.701-14$ & 2.779.23 \\
\hline Radius $=0 \mathrm{~km}, H$ eight $=1 \mathrm{~km}$ & 8.308-12 & $1.364-21$ & $8.296-12$ & 3.494-21 \\
\hline Radius $=0 \mathrm{~km}$, Height $=10 \mathrm{~km}$ & $8.726 \cdot 14$ & $1.409-23$ & $8.615-14$ & $3.580-23$ \\
\hline Radius $=1 \mathrm{~km}$. Height $=1 \mathrm{~km}$ & $3.862-12$ & $6.336-22$ & $3.854-12$ & $1.622-21$ \\
\hline Radius $=10 \mathrm{~km}$, Height $=10 \mathrm{~km}$ & $3.741-14$ & $6.004-24$ & $3.677-14$ & $1.517-23$ \\
\hline
\end{tabular}

'Fluence Units are particles $/ \mathrm{cm}^{2}$ per Source Particle.

'Neutron Dose per Source Neutron

'Gamma-Ray Dose per Source Gamma Ray 
Table 9. Calculated Neutron and Gamma-Ray Doses to Silicon Components in the SBI Weapon Platform $C^{3}$ Bay Critical Components Box Due to a Thermonuclear Weapon Detonation.

Fully Loaded Platform

\begin{tabular}{|c|c|c|c|}
\hline $\begin{array}{l}\text { Position of Platform } \\
\text { (Relative to Source) }\end{array}$ & $\begin{array}{l}\text { Neutron Dose } \\
(\mathrm{cGy})\end{array}$ & $\begin{array}{c}\text { Gamma Dose" } \\
\text { (cGy) }\end{array}$ & $\begin{array}{l}\text { Total Dose } \\
\text { (cGy) }\end{array}$ \\
\hline $\begin{array}{c}\text { Radius }=1 \text { lm Height }=0 \mathrm{~km} \\
\text { Top }^{1} \\
\text { Side }^{2} \\
\text { Bottom }\end{array}$ & $\begin{array}{l}1.702-22^{a} \\
1.838-22 \\
1.965-22\end{array}$ & $\begin{array}{l}1.017-21 \\
8.552-22 \\
7.622-22\end{array}$ & $\begin{array}{l}1.187-21 \\
1.039-21 \\
9.587-22\end{array}$ \\
\hline $\begin{array}{c}\text { Radius }=10 \mathrm{~km}, \mathrm{Height}=0 \mathrm{~km} \\
\text { Top } \\
\text { Side } \\
\text { Bottom }\end{array}$ & $\begin{array}{l}1.572-24 \\
1.692-24 \\
1.804-24\end{array}$ & $\begin{array}{l}9.279-24 \\
7.840-24 \\
7.020-24\end{array}$ & $\begin{array}{l}1.085-23 \\
9.532-24 \\
8.824-24\end{array}$ \\
\hline$\frac{\text { Radius }=0 \mathrm{~km} . \text { Height }=1 \mathrm{~km}}{\text { End }^{4}}$ & $1.698-22$ & 7.728-22 & $9.426-22$ \\
\hline$\frac{\text { Radius }=0 \mathrm{rm}, \mathrm{Hej} h \mathrm{~h}=10 \mathrm{rm}}{\text { End }}$ & $1.768-24$ & $8.082-24$ & $9.850-24$ \\
\hline $\begin{array}{c}\text { Rodius }=1 \mathrm{~km}, \text { Heisht }=1 \mathrm{~km} \\
\text { Top } \\
\text { Side } \\
\text { Bottom }\end{array}$ & $\begin{array}{l}4.983-22 \\
4.247-22 \\
3.632-22\end{array}$ & $\begin{array}{l}1.525-21 \\
1.225-21 \\
1.272-21\end{array}$ & $\begin{array}{l}2.023-21 \\
1.650-21 \\
1.635-21\end{array}$ \\
\hline $\begin{array}{c}\text { Radius }=10 \mathrm{~km}, \text { Height }=10 \mathrm{~km} \\
\text { Top } \\
\text { Side } \\
\text { Bottom }\end{array}$ & $\begin{array}{l}4.533-24 \\
4.149-24 \\
3.463-24\end{array}$ & $\begin{array}{l}1.443-23 \\
1.194-23 \\
1.222-23\end{array}$ & $\begin{array}{l}1.896-23 \\
1.609-23 \\
1.568-23\end{array}$ \\
\hline
\end{tabular}

- Neutron Dose per Source Neutron

"Gamma-Ray Dose per Source Gamma Ray

Read as $1.702 \times 10^{-2}$
${ }^{1}$ Top = Top (antenna) facing the source

2 Side $=$ Side facing the source (an average of 2 rotations)

${ }^{3}$ Bottom = Bottom facing the source

${ }^{4}$ End $=$ End facing the source (an average of 4 rotations) 
Table 10. Calculated Neutron and Gamma-Ray Doces to Silicon Components in the SBI Weapon Platform $C^{3}$ Bay Critical Components Box Due to a Thermonuclear Weapon Detonation.

Center KKVs Launcted

\begin{tabular}{|c|c|c|c|}
\hline $\begin{array}{l}\text { Position of Platform } \\
\text { (Relative to Source) }\end{array}$ & $\begin{array}{l}\text { Neutron Dose' } \\
\text { (cGy) }\end{array}$ & $\begin{array}{c}\text { Gamma Dose" } \\
\text { (cGy) }\end{array}$ & $\begin{array}{l}\text { Total Dose } \\
\text { (cGy) }\end{array}$ \\
\hline $\begin{array}{c}\text { Radius }=1 \mathrm{~km} . \text { Height }=0 \mathrm{~km} \\
\text { Top } \\
\text { Side }^{2} \\
\text { Bottom }^{3}\end{array}$ & $\begin{array}{l}1.516-22 \\
1.805-22 \\
2.092-22\end{array}$ & $\begin{array}{l}1.012-21 \\
8.771-22 \\
9.962-22\end{array}$ & $\begin{array}{l}1.164-21 \\
1.058-21 \\
1.205-21\end{array}$ \\
\hline$\frac{\text { Redius }=0 \mathrm{~km}, \text { Heisht }=1 \mathrm{~lm}}{\text { End }^{4}}$ & $1.260 \cdot 21$ & $3.308-21$ & 4.568-21 \\
\hline $\begin{array}{c}\text { Bodius=1 } \mathrm{km}, \text { Height=1 } \mathrm{km} \\
\text { Top } \\
\text { Side } \\
\text { Bottom }\end{array}$ & $\begin{array}{l}4.653-22 \\
4.002-22 \\
3.905-22\end{array}$ & $\begin{array}{l}1.351-21 \\
1.211-21 \\
1.160-21\end{array}$ & $\begin{array}{l}1.816-21 \\
1.611-21 \\
1.551-21\end{array}$ \\
\hline
\end{tabular}

- Neutron Dase per Source Neutron

“Gamma-Ray Dose per Source Gamma Ray

Read as $1.516 \times 10^{-2}$
${ }^{1}$ Top $=$ Top (antenna) facing the source

${ }^{2}$ Side $=$ Side facing the source (an average of 2 rotations)

${ }^{3}$ Bottom $=$ Bottom facing the source

${ }^{4}$ End $=$ End facing the source (an average of 4 rotations) 
Table 11. Calculated Neutron and Gamma-Ray Dowes to Sillicon Components in the SBI Weapon Platform C' Bay Critical Components Box Due to a Thermonuclear Weapon Detonation.

Top and Bottom EXVs Launched

\begin{tabular}{|c|c|c|c|}
\hline $\begin{array}{l}\text { Position of Platform } \\
\text { (Relattve to Source) }\end{array}$ & $\begin{array}{l}\text { Neutron Dose } \\
\text { (COy) }\end{array}$ & $\begin{array}{c}\text { Gamma Doce" } \\
\text { (COy) }\end{array}$ & $\begin{array}{l}\text { Total Dose } \\
\text { (CGy) }\end{array}$ \\
\hline 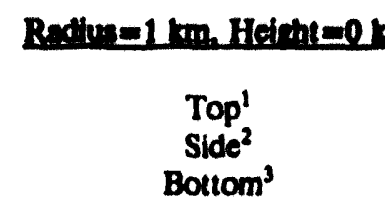 & $\begin{array}{l}1.633-22 \\
1.713-22 \\
1.673-22\end{array}$ & $\begin{array}{l}9.804-22 \\
7.828-22 \\
7.119-22\end{array}$ & $\begin{array}{l}1.144-21 \\
9.541-22 \\
8.792-22\end{array}$ \\
\hline 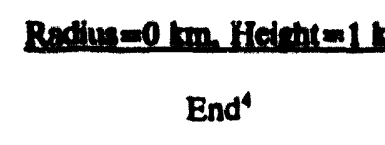 & 1.227.22 & 6.285 .22 & $7.512-22$ \\
\hline $\begin{array}{c}\text { Rediug }=1 \text { tom Heisth }=11 \\
\text { Top } \\
\text { Side } \\
\text { Bottom }\end{array}$ & $\begin{array}{l}4.485-22 \\
4.425 .22 \\
3.596-22\end{array}$ & $\begin{array}{l}1.469-21 \\
1.265-21 \\
1.346-21\end{array}$ & $\begin{array}{l}1.918-21 \\
1.708-21 \\
1.706-21\end{array}$ \\
\hline
\end{tabular}

Neutron Dose per Source Neutron

"Gamma-Ray Dose per Source Gamma Ray "Read as $1.633 \times 10^{-2}$
'Top = Top (antenna) facing the source ${ }^{2}$ Side $=$ Side facing the source (an average of 2 rotations) ${ }^{3}$ Bottom $=$ Bottom facing the source

${ }^{4}$ End = End facing the source (an average of 4 rotations) 
Table 12. Calculated Neutron and Gamma-Ray Protection and Reduction Factors for Sillicon Components in the SBI Weapon Ptatform C' Bay Critical Componenis Box Due 10 a Thermonuclear Weapon Detonation.

Pully Londed Pration

\begin{tabular}{|c|c|c|c|c|c|}
\hline $\begin{array}{l}\text { Poultion of Platform } \\
\text { (Relative to Source) }\end{array}$ & $\begin{array}{l}\text { Neutron } \\
\text { Protection } \\
\text { Factor }\end{array}$ & $\begin{array}{l}\text { Gamma-Ray } \\
\text { Protection } \\
\text { Factor }\end{array}$ & $\begin{array}{l}\text { Total } \\
\text { Protection } \\
\text { Factor }\end{array}$ & $\begin{array}{l}\text { Neutron } \\
\text { Reduction } \\
\text { Factor }\end{array}$ & $\begin{array}{l}\text { Gamma-Ray } \\
\text { Reduction } \\
\text { Factor }\end{array}$ \\
\hline 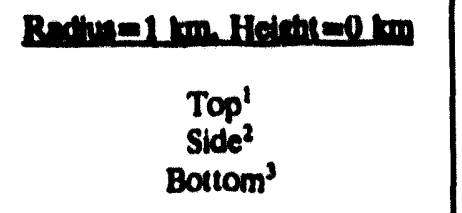 & $\begin{array}{l}1.47 \\
1.96 \\
1.91\end{array}$ & $\begin{array}{l}8.68 \\
7.44 \\
9.68\end{array}$ & $\begin{array}{l}3.65 \\
4.17 \\
4.52\end{array}$ & $\begin{array}{l}7.15 \\
6.62 \\
6.20\end{array}$ & $\begin{array}{l}3.07 \\
3.65 \\
4.09\end{array}$ \\
\hline 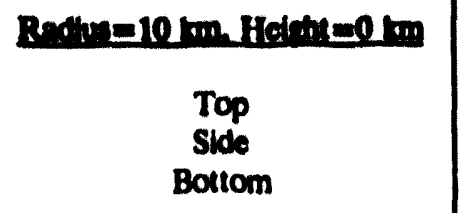 & $\begin{array}{l}1.45 \\
1.93 \\
1.88\end{array}$ & $\begin{array}{l}8.38 \\
7.22 \\
9.32\end{array}$ & $\begin{array}{l}3.57 \\
4.06 \\
4.39\end{array}$ & $\begin{array}{l}6.97 \\
6.48 \\
6.07\end{array}$ & $\begin{array}{l}3.00 \\
3.54 \\
3.96\end{array}$ \\
\hline $\begin{array}{c}\text { R-dine }=0 \text { rom Helshe }=1 \mathrm{~lm} \\
\text { End }^{4}\end{array}$ & 3.20 & 6.77 & 5.15 & 8.04 & 4.52 \\
\hline 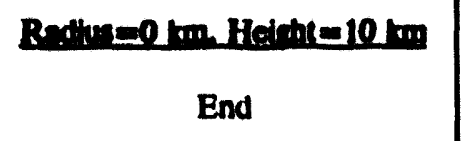 & 3.14 & 6.69 & 5.07 & 7.97 & 4.43 \\
\hline 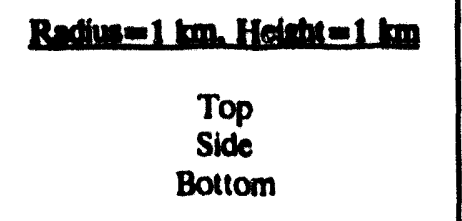 & $\begin{array}{l}0.65 \\
0.84 \\
0.90\end{array}$ & $\begin{array}{l}1.55 \\
1.80 \\
1.74\end{array}$ & $\begin{array}{l}1.12 \\
1.37 \\
1.38\end{array}$ & $\begin{array}{l}1.27 \\
1.49 \\
1.74\end{array}$ & $\begin{array}{l}1.06 \\
1.32 \\
1.28\end{array}$ \\
\hline 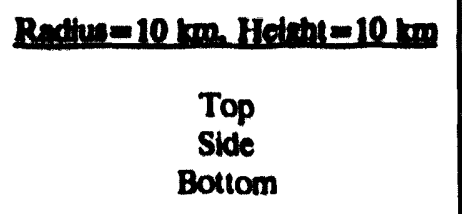 & $\begin{array}{l}0.68 \\
0.82 \\
0.89\end{array}$ & $\begin{array}{l}1.50 \\
1.73 \\
1.69\end{array}$ & $\begin{array}{l}1.12 \\
1.32 \\
1.35\end{array}$ & $\begin{array}{l}1.33 \\
1.45 \\
1.73\end{array}$ & $\begin{array}{l}1.05 \\
1.27 \\
1.24\end{array}$ \\
\hline
\end{tabular}

'Top = Top (antenna) facing the source

2Side = Side facing the source (an average of 2 rotations)

BBottom = Bottom facing the source

End = End facing the source (an average of 4 rotations) 
Table 13. Calculated Neutron and Gamma-Ray Protection and Reduction Factors for Silicon Components in the SBI Weapon Platform $C^{3}$ Bay Critical Components Box Due to a Thermonuclear Weapon Detonation.

Center KXVs Lunched

\begin{tabular}{|c|c|c|c|c|c|}
\hline $\begin{array}{l}\text { Position of Platform } \\
\text { (Relative to Source) }\end{array}$ & $\begin{array}{l}\text { Neutron } \\
\text { Protection } \\
\text { Factor }\end{array}$ & $\begin{array}{l}\text { Gamma-Ray } \\
\text { Protection } \\
\text { Factor }\end{array}$ & $\begin{array}{l}\text { Total } \\
\text { Protection } \\
\text { Factor }\end{array}$ & $\begin{array}{l}\text { Neutron } \\
\text { Reduction } \\
\text { Factor }\end{array}$ & $\begin{array}{c}\text { Gamma-Ray } \\
\text { Reduction } \\
\text { Factor }\end{array}$ \\
\hline $\begin{array}{c}\text { Rofine } 1 \text { inh Helthteo } \\
\text { Top' } \\
\text { Side }^{2} \\
\text { Bottom }^{3}\end{array}$ & $\begin{array}{l}1.71 \\
1.93 \\
1.60\end{array}$ & $\begin{array}{l}6.87 \\
7.28 \\
7.00\end{array}$ & $\begin{array}{l}3.73 \\
4.10 \\
3.60\end{array}$ & $\begin{array}{l}8.03 \\
6.74 \\
5.82\end{array}$ & $\begin{array}{l}3.08 \\
3.56 \\
3.13\end{array}$ \\
\hline $\begin{array}{c}\text { Redinge0lan Heitet =1 } \\
\text { End }^{4}\end{array}$ & 0.76 & 1.26 & 1.06 & 1.08 & 1.06 \\
\hline $\begin{array}{c}\text { Radiun }=1 \text { km Hetht }=1 \\
\text { Top } \\
\text { Side } \\
\text { Elottom }\end{array}$ & $\begin{array}{l}0.75 \\
0.92 \\
0.88\end{array}$ & $\begin{array}{l}1.66 \\
1.76 \\
1.95\end{array}$ & $\begin{array}{l}1.24 \\
1.40 \\
1.46\end{array}$ & $\begin{array}{l}1.36 \\
1.58 \\
1.62\end{array}$ & $\begin{array}{l}1.20 \\
1.34 \\
1.40\end{array}$ \\
\hline
\end{tabular}

${ }^{1}$ Top $=$ Top (antenna) facing the source

2Side = Side facing the source (an average of 2 rotations)

Bottom = Bottom facing the source

${ }^{4}$ End = End facing the source (an average of 4 rotations) 
Table 14. Calculated Neutron and Gamma-Ray Protection and Reduction Factors for Silicon Components in the SBI Weapon Platform C' Bay Critical Components Box Due to a Thermonuclear Weapon Detonation.

Top and Botton KXVS Launched

\begin{tabular}{|c|c|c|c|c|c|}
\hline $\begin{array}{l}\text { Position of Platform } \\
\text { (Relative to Source) }\end{array}$ & $\begin{array}{l}\text { Neutron } \\
\text { Protection } \\
\text { Factor }\end{array}$ & $\begin{array}{l}\text { Gamma-Ray } \\
\text { Protection } \\
\text { Factor }\end{array}$ & $\begin{array}{l}\text { Total } \\
\text { Protection } \\
\text { Factor }\end{array}$ & $\begin{array}{l}\text { Neutron } \\
\text { Reduction } \\
\text { Factor }\end{array}$ & $\begin{array}{c}\text { Gamma-Ray } \\
\text { Reduction } \\
\text { Factor }\end{array}$ \\
\hline $\begin{array}{c}\text { Redin: }=1 \text { tom. Heitht }=0 \\
\text { Top' } \\
\text { Side }^{2} \\
\text { Bottom }^{3}\end{array}$ & $\begin{array}{l}1.78 \\
2.09 \\
2.23\end{array}$ & $\begin{array}{l}6.81 \\
8.38 \\
9.37\end{array}$ & $\begin{array}{l}3.79 \\
4.55 \\
4.93\end{array}$ & $\begin{array}{l}7.46 \\
7.11 \\
7.28\end{array}$ & $\begin{array}{l}3.18 \\
3.98 \\
4.38\end{array}$ \\
\hline $\begin{array}{c}\text { Reting }=0 \text { Lm Heint }=1 \\
\text { End }^{4}\end{array}$ & 3.43 & 9.88 & 6.47 & 11.12 & 5.56 \\
\hline $\begin{array}{c}\text { Rodius }=1 \text { hm. Heicht }=1 \\
\text { Top } \\
\text { Side } \\
\text { Bottom }\end{array}$ & $\begin{array}{l}0.77 \\
0.83 \\
0.89\end{array}$ & $\begin{array}{l}1.48 \\
1.71 \\
1.63\end{array}$ & $\begin{array}{l}1.18 \\
1.32 \\
1.32\end{array}$ & $\begin{array}{l}1.41 \\
1.43 \\
1.76\end{array}$ & $\begin{array}{l}1.10 \\
1.28 \\
1.21\end{array}$ \\
\hline
\end{tabular}

${ }^{1}$ Top $=$ Top (antenna) facing the source

'Side $=$ Side facing the source (an average of 2 rotations)

${ }^{3}$ Bottom $=$ Bottom facing the source

${ }^{4}$ End = End facing the source (an average of 4 rotations) 
critical components box when the source is on-axis with the platform (Table 10, $r=0 \mathrm{~km}, z=1$ $\mathrm{km}$ ). When compared to the fully loaded platform, the results indicate approximately a factor of seven more neutron dose and a factor of four more gamma-ray dose. The results for the other two source/platform orientations indicate very little differences.

The protection factor and reduction factor results in Tables 12 through 14 support the dose results in Tables 9 through 11 discussed above. For the fully loaded platform (Table 12) and the platform with the top and bottom KKVs launched (Table 14), the higher protection and reduction factors are evidenced by the source facing the top of the platform $(r=1 \mathrm{~km}$, $z=0 \mathrm{~km})$ or facing the end of the platform $(r=0 \mathrm{~km}, z=1 \mathrm{~km})$. The effects of limited engagement are seen when comparing the fully loaded (Table 12) and center launched (Table 13) interceptor cases where the protection factors decrease by approximately a factor of four for the source on-axis facing one set of $\mathrm{KKV}$ launch tubes $(r=0 \mathrm{~km}, z=1 \mathrm{~km})$. It is interesting to note that the neutron protection factor is less than one for this case. This is due to the secondary gamma-ray production in the platform components contributing to the dose in the critical components box.

Finally it should be noted that for the last case $(r=1 \mathrm{~km}, z=1 \mathrm{~km})$, the source has a direct line-of-sight to the critical components box regardless of the number of interceptors present. For all three platform configurations, the results in Tables 12 through 14 indicate neutron protection factors less than one, marginal gamma-ray protection factors (less than a factor of two), and total protection factors less than 1.50. The neutron protection factors less than one are again due to the secondary gamma-ray production in the platform components contributing to the dose in the critical components box. 


\subsection{CONCLUSIONS AND RECOMMENDATIONS}

The results indicate that for certain source/platform orientations, the $\mathrm{C}^{3}$ bay critical components box is vulnerable to radiation damage from a nuclear weapon detonation. Neutron protection factors ranged from 0.7 to 3.4 for the three platform configurations analyzed, and gamma-ray protection factors ranged from approximately 1.5 to 9.8 . The results further indicate the source has a direct line-of-sight to the critical components box for certain source/platform orientations, regardless of the number of interceptors present. Localized shielding of the $\mathrm{C}^{3}$ bay critical components box (and probably the inner and outer instrument rings) would be necessary to successfully mitigate all radiation line-of-sight pathways into the electronic bays.

Absolute doses or dose rates were not determined in this report. The tables give doses (or dose rates) per incident source particle, which allows the absolute values to be determined once the weapon parameters (size and yield) are known. The changes in the electrical characteristics which can result in degradation of circuit performance, radiation induced photo currents, transient circuit upsets, or device failure are a function of the hardness of the electronics, and the source to platform distance. Given the radiation performance characteristics of the electronic equipment, the spacecraft designer can calculate the distance at which damage occurs by using source information on the weapon yield (n, $\gamma /$ kiloton) and size (number of kilotons).

The geometry configuration studied here is greatly simplified compared to those that will be encountered in an actual design. The MASH code system is capable of estimating the dose in much more complicated geometries and should prove to be an invaluable tool for assessing the radiation effects of both on-spacecraft and external radiation sources to electronic equipment. Performing radiation vulnerability calculations and localized shielding calculations when a space-based asset is in the design stage eliminates costly retro-fitting and typically allows the designer more flexibility in accommodating needed design changes. Combining the MASH code system with other codes that estimate natural radiation effects will provide satellite and weapon platform designers with a full complement of analytic tools. 


\subsection{REFERENCES}

1. J. O. Johnson, ed., "A User's Manual for MASH 1.0 - A Monte Carlo Adjoint Shielding Code System," ORNL/TM-11778, Oak Ridge National Laboratory, (March 1992).

2. R. T. Santoro and T. A. Gabriel, "Shield Optimization Program, Part I: Executive Summary," ORNL/TM-11143, Oak Ridge National Laboratory, (June 1989).

3. J. O. Johnson, "Analysis of the Radiological Test Configuration (RTK) Experiments Using the Monte Carlo Code System - MASH," ORNL/TM-11410, Oak Ridge National Laboratory, (March 1990).

4. J. O. Johnson, J. D. Drischler, and J. M. Barnes, "Analysis of the Fall-1989 Two-Meter Box Test Bed Experiments Performed at the Army Pulse Radiation Facility (APRF)," ORNL/TM-11777, Oak Ridge National Laboratory, (May 1991).

5. J. O. Johnson, J. D. Drischler, and J. M. Barnes, "Analysis of the Spring-1990 Two-Meter Box Test Bed Experiments Performed at the Army Pulse Radiation Facility (APRF)," ORNL/TM-11917, Oak Ridge National Laboratory, (August 1992).

6. J. O. Johnson, J. D. Drischler, and J. M. Barnes, "Analysis of the Spring-1991 Two-Meter Box Test Bed Experiments Performed at the Army Pulse Radiation Facility (APRF)," ORNL/TM-11918, Oak Ridge National Laboratory, (September 1992).

7. J. M. Barnes, J. O. Johnson, T. J. Burns, and J. D. Drischler, "Nuclear Vulnerability of the U.S. M60A1 Tank in an Initial Radiation Environment: MASH Code System Analysis," ORNL/TM-11775, Oak Ridge National Laboratory, (May 1991).

8. W. A. Rhoades and R. L. Childs, "The DORT Two-Dimensional Discrete Ordinates Transport Code," Nuclear Science \& Engineering 99, 1, 88-89 (May 1988).

9. M. B. Emmett, "The MORSE Monte Carlo Radiation Transport Code System," ORNL-4972 (1975), ORNL-4972/R1 (1983), ORNL-4972/R2 (1984), Oak Ridge National Laboratory.

10. D. T. Ingersoll, R. W. Roussin, C. Y. Fu, and J. E. White, "DABL69: A Broad-Group Neutron/Photon Cross-Section Library for Defense Nuclear Applications," ORNL/TM-10568, Oak Ridge National Laboratory, (June 1989).

11. L. W. Bain, Jr. and M. J. Reisinger, "The GIFT Code Users Manual; Volume I, Introduction and Input Requirements," BRL Report No. 1802, AD B0060371, Ballistic Research Laboratory, (July 1975). 
12. G. G. Kuehl, L. W. Bain, Jr., and M. J. Reisinger, "The GIFT Code Users Manual; Volume II, The Output Options," ARBRL-TR-02189, AD A078364, Ballistic Research Laboratory, (September 1979). 
ORNL/TM-12487

\section{INTERNAL DISTRIBUTION}

1. J. M. Barnes

2. T. J. Burns

3. J. D. Drischler

4. C. M. Haaland

5. D. T. Ingersoll

6-10. J. O. Johnson

11. C. E. Oliver

12-16. J. V. Pace

17. C. O. Slater
18. R. W. Roussin

19. R. C. Ward

20-21. EPMD Reports Office

22-23. Laboratory Records Department

24. Laboratory Records ORNL-RC

25. Documents Reference Section

26. Central Research Library

27. ORNL Patent Section

\section{EXTERNAL DISTRIBUTION}

28-37. Director

U.S. Army Research Laboratory

ATTN: AMSRL-WT-NH (Mr. Kerris)

2800 Powder Mill Road

Adelphi, MD 20783-1145

38. Commander

U.S. Army Nuclear and Chemical Agency

ATTN: MONA-ZB (Dr. Davidson)

7500 Backlick Rd., Building 5073

Springfield, VA 22150-3198

39. Commander

U.S. Army Nuclear and Chemical Agency

ATTN: MONA-NU (Dr. Bash)

7500 Backlick Rd., Building 5073

Springfield, VA 22150-3198

40-44. Director

Defense Nuclear Agency

ATTN: RAEM (Mr. Kehlet)

6801 Telegraph Road

Alexandria, VA 22310-3398 
45. Director

U.S. Army Foreign Science and Technology Center

ATTN: IAAIF-RTC (Dr. Ward)

220 Seventh Street, NE

Charlottesville, VA 22901-5396

46. TRW System Development Division

Huntsville Operations

ATTN: Mr. Joe P. Holland

213 Wynn Drive

Huntsville, AL 35805

47. R. T. Santoro

ITER Garching Joint Work Site

Max-Planck-Insitut Fur Plasmphysik

Boltzmannstrasse 2

D-85748 Garching bei Munchen

GERMANY

48-49. Office of Scientific \& Technical Information

P.O. Box 62

Oak Ridge, TN 37830

50. Prof. Roger W. Brockett

Harvard University

Pierce Hall

29 Oxford Street

Cambridge, MA 02138

51. Prof. Donald Dudziak

Depart. of Nuclear Engineering

110B Burlington Engineering Labs

North Carolina State University

Raleigh, NC 27695-7909

52. Director, Defense Nuclear Agency

ATTN: RAEM (Mr. Gullickson)

6801 Telegraph Road

Alexandria, VA 22310-3398

53. Dr. N. Ricky Byrn

Nicholes Research Corp.

4040 So. Memorial Parkway

Huntsville, AL 35802

54. Science Application Internation Corporation

ATTN: Dr. Stephen Egbert

10260 Campus Point Drive

San Diego, CA 92121 
55. Science Application International Corporation

ATTN: Dr. Dean C. Kaul 10260 Campus Point Drive

San Diego, CA 92121

56. Director, Defense Nuclear Agency

ATTN: OFRA (Ms. Joan Ma Pierre)

6801 Telegraph Road

Alexandria, VA 22310-3398

57. Director, Defense Nuclear Agency

ATTN: OFA (Col Michael Callaway)

6801 Telegraph Road

Alexandria, VA 22310-3398

58. Commander, US Army Foreign Science \& Technology Center

ATTN: UVA (Dr. Roger Rydin)

2207 th Street NE

Charlottesville, VA 22901-5396

59. David L. Tilson

U.S. Army SDC

ATTN: CDDS-SA-EV

P.O. Box 1500

Huntsville, AL 35807

60. Director, Defense Nuclear Agency

ATTN: RAES ( MR. R. C. Webb)

6801 Telegraph Road

Alexandria, VA 22310-3398

61. Office of the Assistant Manger for Energy

Research and Development

Department of Energy, Oak Ridge Operations

P.O. Box 2001

Oak Ridge, TN 37831

62. Director, Defense Nuclear Agency

ATTN: Ms. Gracie Davis

6801 Telegraph Road

Alexandria, VA 22310-3398

63. Dr. Matthew H. Appleby

Doeing Defense \& Space Group

Missiles and Space Division

Concepts \& Product Development

499 Goeing Boulevard

Mail Stop JW-21

Huntsville, AL 35824-6402 
64-68.

C. L. Perez 9529 Gulf Park Drive

Knoxville, TN 37923 

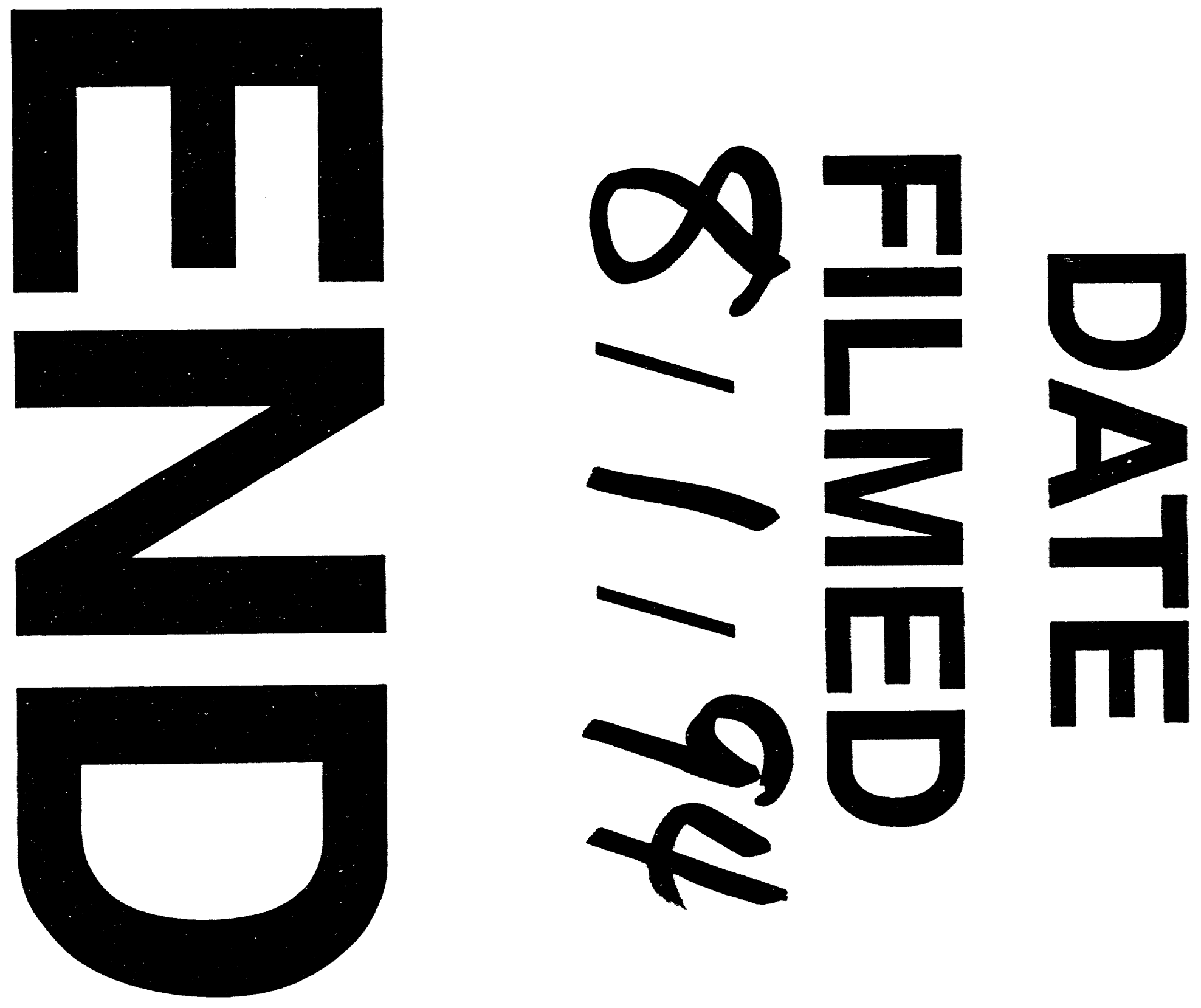


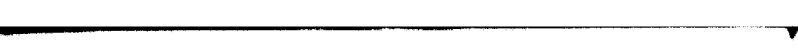
(
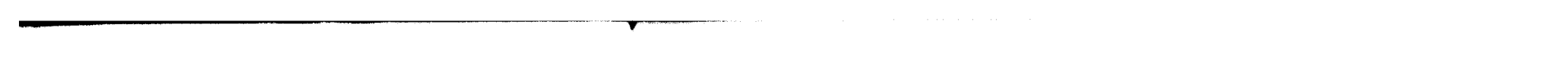

列 